\title{
Peripheral Gene Therapeutic Rescue of an Olfactory Ciliopathy Restores Sensory Input, Axonal Pathfinding, and Odor-Guided Behavior
}

\author{
Warren W. Green, ${ }^{1,2}$ Cedric R. Uytingco, ${ }^{1,2}$ Kirill Ukhanov, ${ }^{1,2}$ Zachary Kolb, ${ }^{1}$ Jordan Moretta, ${ }^{1}$ Jeremy C. McIntyre, ${ }^{1.3}$ \\ and Jeffrey R. Martens ${ }^{1,2}$ \\ ${ }^{1}$ Department of Pharmacology and Therapeutics, University of Florida, College of Medicine, Gainesville, Florida 32610, ${ }^{2}$ University of Florida Center for \\ Smell and Taste, Gainesville, Florida 32610, and 3Department of Neuroscience, University of Florida, College of Medicine, Gainesville, Florida 32610
}

Cilia of olfactory sensory neurons (OSNs) are the primary site of odor binding; hence, their loss results in anosmia, a clinical manifestation of pleiotropic ciliopathies for which there are no curative therapies. We used OSN-specific Ift 88 knock-out mice $\left(\mathrm{Ift} f 8^{\text {osnKo }}\right)$ of both sexes to examine the mechanisms of ciliopathy-induced olfactory dysfunction and the potential for gene replacement to rescue odorant detection, restore olfactory circuitry, and restore odor-guided behaviors. Loss of OSN cilia in Ift8 ${ }^{\circ s n K O}$ mice resulted in substantially reduced odor detection and odor-driven synaptic activity in the olfactory bulb (OB). Defects in OSN axon targeting to the OB were also observed in parallel with aberrant odor-guided behavior. Intranasal gene delivery of wild-type IFT 88 to Ift $88^{\text {osnKo }}$ mice rescued OSN ciliation and peripheral olfactory function. Importantly, this recovery of sensory input in a limited number of mature OSNs was sufficient to restore axonal targeting in the $\mathrm{OB}$ of juvenile mice, and with delayed onset in adult mice. In addition, restoration of sensory input re-established course odor-guided behaviors. These findings highlight the spare capacity of the olfactory epithelium and the plasticity of primary synaptic input into the central olfactory system. The restoration of peripheral and central neuronal function supports the potential for treatment of ciliopathy-related anosmia using gene therapy.

Key words: axon wiring; behavior; cilia; ciliopathies; olfactory bulb; olfactory sensory neuron

Significance Statement

Ciliopathies, for which there are no curative therapies, are genetic disorders that alter cilia morphology and/or function in numerous tissue types, including the olfactory system, leading to sensory dysfunction. We show that in vivo intranasal gene delivery restores peripheral olfactory function in a ciliopathy mouse model, including axonal targeting in the juvenile and adult olfactory bulb. Gene therapy also demonstrated restoration of olfactory perception by rescuing odor-guided behaviors. Understanding the therapeutic window and viability for gene therapy to restore odor detection and perception may facilitate translation of therapies to ciliopathy patients with olfactory dysfunctions.

\section{Introduction}

The olfactory system in animals and humans detect a diverse array of volatile chemicals or odorants in the external environ-

Received Jan. 12, 2018; revised July 9, 2018; accepted July 11, 2018.

Author contributions: W.W.G. wrote the first draft of the paper; C.R.U., K.U., J.C.M., and J.R.M. edited the paper. W.W.G., J.C.M., and J.R.M. designed research; W.W.G., C.R.U., K.U., Z.K., J.M., and J.C.M. performed research; W.W.G., C.R.U., K.U., Z.K., and J.C.M. analyzed data; W.W.G. and C.R.U. wrote the paper.

This work was supported by National Institute of Health Grants R01-DC-009606 (J.R.M.), F32-DC-011990 (J.C.M.), and K99-DC-01355 (J.C.M.).We thank Dr. Daniel Wesson and Dr. Steven Munger for feedback during writing of the paper, and Dr. Cory Root for sharing the design of the four-quadrant open-field behavior chamber and for assistance during development of this assay in our laboratory.

The authors declare no competing financial interests.

Correspondence should be addressed to Dr. Jeffrey R. Martens, Pharmacology and Therapeutics, University of Florida, College of Medicine, 1200 Newell Drive, ARB R5-234A, Gainesville, FL 32610-0267. E-mail: martensj@ufl.edu. ment. These odorants function to identify foods and their quality, reproductive status, and potential dangers, such as toxins or predators. The perception of these odorants ultimately mediates behaviors important for feeding, reproduction, survival, and overall quality of life (Blass and Teicher, 1980; Wysocki and Lepri, 1991; Stowers et al., 2002; Papes et al., 2010; Ferrero et al., 2011; Gopinath et al., 2011; Logan et al., 2012; Dewan et al., 2013; Doty and Kamath, 2014; Li and Liberles, 2015; Saraiva et al., 2016). Odorants are detected by the multiciliated olfactory sensory neurons (OSNs), which reside in the olfactory epithelium (OE) of the nasal cavity. The OSN cilia contain all of the components for odor detection and extend from the apical dendrite, 
forming a ciliary entanglement on the $\mathrm{OE}$ surface (Firestein, 2001).

Ciliopathies are a group of pleiotropic congenital diseases where cilia structure and/or function are disrupted. The list of known diseases includes Bardet-Biedl syndrome (BBS), Joubert syndrome, Leber congenital amaurosis (LCA), Meckel-Gruber syndrome (MKS), and polycystic kidney disease (PKD), among others (Reiter and Leroux, 2017). Clinical manifestations of ciliopathies exhibit variable penetrance in multiple organ systems depending on genetic background, the afflicted gene, and the type of mutation (Ware et al., 2011; Reiter and Leroux, 2017). Ciliopathy phenotypes can include renal cysts, polydactyly, obesity, cognitive disorders, and sensory deficits such as anosmia. Although studies examining the penetrance of ciliopathies in the olfactory system have been limited, it is apparent from patients and mouse models that ciliopathies can cause loss of odor detection, aberrant OSN axon wiring, and disruption of olfactorymediated behaviors (Kulaga et al., 2004; Nishimura et al., 2004; Eichers et al., 2006; McEwen et al., 2007; Tadenev et al., 2011; McIntyre et al., 2012; Williams et al., 2017).

The generation and maintenance of cilia, including olfactory cilia, are highly dependent on intraflagellar transport (IFT), where the IFT 88 protein plays a critical role in the ciliary protein trafficking. Global IFT-associated gene mutations are early postnatal or embryonic lethal (Pazour and Rosenbaum, 2002; Rosenbaum and Witman, 2002; McIntyre et al., 2012), which precludes examination of central olfactory phenotypes and the assessment of gene therapy to restore odor perception. Previously, we demonstrated that in vivo intranasal viral gene delivery is capable of rescuing peripheral olfactory function (McIntyre et al., 2012; Williams et al., 2017). To address the contribution of OSN cilia loss to aberrant axon wiring and odor-guided behavior, and the potential of gene therapeutic reversal of these defects, we used an OSN-specific Ift88 knock-out mouse model that exhibit olfactory ciliary loss. More importantly, use of this mouse model allowed for examination of the therapeutic potential of intranasal gene therapy in a severe ciliopathy and its potential for restoring olfactory-mediated behaviors in ciliopathy patients. We show that in vivo ectopic expression of IFT88 is sufficient to restore ciliation and function of mature OSNs in our olfactory-specific ciliopathy model. Notably, we demonstrate that in vivo gene therapy can rescue defective OSN axon wiring in both the developing and adult olfactory systems, as well as restore course olfactorymediated behaviors in adult mice. Surprisingly, restoration of sensory input in a limited number of solitary OSNs was sufficient to induce refinement of axonal targeting and translate odor detection to behavior, highlighting the spare capacity in the olfactory system. Furthermore, our findings point at a broad therapeutic window extending from development to adulthood for ciliopathy-induced olfactory dysfunctions.

\section{Materials and Methods}

Mice. Conditional deletion of Ift88 from olfactory sensory neurons was achieved by crossing mice containing the heterozygous OMP-Cre allele (The Jackson Laboratory, Stock \#006668, Strain: B6;129P2-

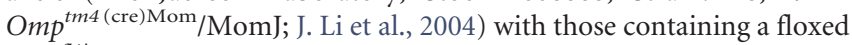
Ift $88^{f / \Delta}$ allele (the $\Delta$ allele has exons 4-6 deleted from Ift 88 ; The Jackson Laboratory, Stock \#022409, Strain: B6;129P2-Ift88 ${ }^{\text {tmtm1Bky }} /$ J; Haycraft et al., 2007), generously provided by B. K. Yoder [University of Alabama at Birmingham, Birmingham, AL (UAB)]. Mice of both sexes were used for all experimentation and were maintained on a mixed genetic background of C57BL/6J and 129/Ola. The resulting OMPCre;Ift $88^{F / F}$ mice possess olfactory sensory neurons that lack cilia. Littermate mice that did not possess the OMP-Cre allele (OMPCre-; Ift $88^{F / F}$ or OMPCre-;Ift $88^{F / W}$ ) were used as wild-type controls in all experiments. OMP-Cre mice were obtained from The Jackson Laboratory (Stock \#006668). The Ift $88^{f / / \Delta}$ mice were provided by Bradley Yoder (UAB). Mice possessing the M71IRES-tauLacZ allele (Feinstein and Mombaerts, 2004) were acquired from The Jackson Laboratory (Stock \#006675) and crossed with the OMPCre; Ift $88^{F / F}$ mice to produce M71iTL;OMPCre;Ift $88^{F / F}$ mice. Wildtype control mice for the M71iTL;OMPCre;Ift88 mice were littermates that did not possess the OMP-Cre allele (either M71iTL;OMPCre-; Ift $88^{F / F}$ or M71iTL;OMPCre-;Ift88 ${ }^{F / W}$ mice). All mice of both sexes were housed and maintained according to the University of Florida institutional guidelines. All protocols for mouse experimentation were approved by the University of Florida Institutional Animal Care and Use Committee (IACUC Protocol 201608162). Genotyping was performed using primers and PCR parameters from previously published work referenced above.

Adenovirus constructs and ectopic gene delivery. Plasmid containing the cDNA insert for IFT88 was a generous gift from B. K. Yoder (UAB). GCaMP6f cDNA was obtained from Addgene (40755). Myristoylatedpalmitoylated-GFP (MP-GFP) and MP-mCherry were described previously (Williams et al., 2014, 2017). IFT88-GFP, IFT88(M383K)-GFP, IFT88-IRES-MP-GFP, IFT88-IRES-MP-mCherry, MP-GFP, MP-mCherry, and GCaMP6f were inserted into the adenoviral vector $\mathrm{pAd} / \mathrm{CMV} / \mathrm{V} 5$ DEST expression vector using Gateway technology (V49320, Invitrogen). Adenoviral vectors were propagated using the ViraPower protocol (Invitrogen) and was purified with the Virapur Adenovirus mini purification Virakit (003059, Virapur) yielding $\sim 10 \times 10^{9}$ plaque forming units (pfu). Following purification, adenoviral vectors were dialyzed in $2.5 \%$ glycerol, $25 \mathrm{~mm}$ $\mathrm{NaCl}$, and $20 \mathrm{~mm}$ Tris-HCl, pH 8.0 (Slide-A-Lyzer Dialysis Cassette, 66383, ThermoFisher Scientific) at $4^{\circ} \mathrm{C}$ overnight. Samples were aliquoted and stored at $-80^{\circ} \mathrm{C}$, until use.

Twenty-microliters of purified and dialyzed adenoviral vector was intranasally administered at room temperature to the $\mathrm{OE}$ of juvenile or adult mice for 3 consecutive days using a pulled $1 \mathrm{ml}$ syringe and trimmed to $0.5 \mathrm{~mm}$ tip (\#309659, BD; McIntyre et al., 2012; Williams et al., 2014, 2017). All mice were positioned vertically and adenoviral solutions were delivered as $1.0 \mathrm{~mm}$ diameter droplets (equivalent to 3-4 $\mu \mathrm{l}$ ) in alternating nostrils, while avoiding the philtrum. For juvenile mice, adenoviral-administration occurred from $\mathrm{P} 7-\mathrm{P} 9$ and mice were analyzed at age P21 or 8 weeks old. For adult mice, adenoviral-administration began at 8 weeks old for 3 consecutive days and mice were analyzed either 2 or 4 weeks later.

Immunohistochemistry. Mice were deeply anesthetized with an intraperitoneal injection of xylazine $(100 \mathrm{mg} / \mathrm{kg})$ and ketamine $(10 \mathrm{mg} / \mathrm{kg})$, transcardially perfused with $4 \%$ paraformaldehyde (PFA) in $1 \times \mathrm{PBS}$, decapitated, and their heads were postfixed in $4 \%$ PFA for $12-16 \mathrm{~h}$ at $4^{\circ} \mathrm{C}$. Tissue was then decalcified in $0.5 \mathrm{M}$ EDTA in $1 \times \mathrm{PBS}, \mathrm{pH} 8.0$, overnight at $4^{\circ} \mathrm{C}$, cryoprotected in $10 \%(1 \mathrm{~h}), 20 \%(1 \mathrm{~h})$, and $30 \%$ sucrose in $1 \times$ PBS overnight at $4^{\circ} \mathrm{C}$, and frozen in optimal cutting temperature (OCT) compound (Tissue-Tek). The $\mathrm{OE}$ and $\mathrm{OB}$ were subsequently sectioned in the coronal plane at a thickness of $10-12 \mu \mathrm{m}$ using a Leica CM1860 cryostat and collected on Superfrost Plus slides (Fisher Scientific). For immunostaining, cryosections were rinsed in $1 \times$ PBS to remove OCT, subsequently permeabilized and blocked with $0.1 \%$ Triton X-100 and $2 \%$ donkey or goat serum in $1 \times \mathrm{PBS}$ for $1 \mathrm{~h}$ at room temperature. Primary antibodies were diluted in $2 \%$ goat or donkey serum in $1 \times$ PBS and incubated overnight at $4^{\circ} \mathrm{C}$. Primary antibodies were used at the following dilutions: rabbit anti-Polaris (IFT88, 1:500; gift from Brad K. Yoder, UAB); goat anti-OMP (1:1000; 544-10001, Wako Chemicals); mouse anti- $\alpha$ acetylated tubulin (1:1000; clone 6-11 B1 \#T6793, SigmaAldrich); rabbit anti- tyrosine hydroxylase (TH; 1:500; MAB318, Millipore); goat anti-Pde2a (1:500; sc-17228, Santa Cruz Biotechnology); and rabbit anti-cleaved caspase-3 (1:400; 9662, Cell Signaling Technology). Sections were washed in $1 \times$ PBS three times for $5 \mathrm{~min}$ each at room temperature and then incubated with fluorescent AlexaFluor-conjugated secondary antibodies ( $\mathrm{H}+\mathrm{L}$ IgG, 1:1000; Invitrogen) for $1 \mathrm{~h}$ at room temperature. Tissue sections were then rinsed with $1 \times$ PBS and incubated with DAPI (Invitrogen; $5 \mathrm{mg} / \mathrm{ml}$ ) for $5 \mathrm{~min}$, washed three times with $1 \times$ PBS, and sealed with coverslips mounted with ProLong Gold (Invitrogen). 
For odorant receptor immunostaining in the $\mathrm{OB}$, the tissue perfusion and immunostaining protocol described above was modified as described by Low and Mombaerts (2017). Mice were anesthetized as described above, transcardially perfused with $2 \%$ PFA in $1 \times$ PBS, decapitated, and mouse heads were postfixed in $2 \%$ PFA in $1 \times$ PBS for $2 \mathrm{~h}$ at $4^{\circ} \mathrm{C}$. Tissue was then decalcified, cryoprotected, embedded in OCT compound (Tissue-Tek), and sectioned as described above. Cryosections were rinsed in $1 \times$ PBS to remove OCT and placed into $6.5 \mathrm{~mm}$ citric acid buffer, $\mathrm{pH}$ 6.0, with $0.2 \%$ Tween 20 . After heating to $95^{\circ} \mathrm{C}$ for $30 \mathrm{~min}$ for antigen retrieval, slides were left to cool for $1 \mathrm{~h}$ in retrieval buffer. Slides were then rinsed in distilled water for $5 \mathrm{~min}$, rinsed three times with $1 \times$ PBS, and blocked in $10 \%$ normal goat serum in $1 \times$ PBS for $1 \mathrm{~h}$ at room temperature. Primary antibody for Olfr 1507 (1:2000; OSenses/Thermofisher, OSR00212W, Rabbit polyclonal) was diluted in $1 \%$ normal goat serum with $0.1 \%$ Triton X-100 in $1 \times$ PBS and incubated overnight at $4^{\circ} \mathrm{C}$. Sections were washed in $1 \times \mathrm{PBS}$ three times for $5 \mathrm{~min}$ each at room temperature and then incubated with goat anti-rabbit AlexaFluor 488 (H+L; 1:1000; Invitrogen) secondary antibody in $1 \%$ normal goat serum with $0.1 \%$ Triton $\mathrm{X}-100$ in $1 \times \mathrm{PBS}$ for $1 \mathrm{~h}$ at room temperature. Slides were rinsed, counterstained with DAPI, and coverslipped as described above.

Images of immunostained tissue were collected on a Nikon TiE-PFSA1R confocal microscope equipped with a $488 \mathrm{~nm}$ laser with a $510-560$ $\mathrm{nm}$ bandpass filter, a $561 \mathrm{~nm}$ laser with a $575-625 \mathrm{~nm}$ bandpass filter, and a $640 \mathrm{~nm}$ laser with a 663-738 bandpass filter using CFI Apochromat Lambda $20 \times(0.75 \mathrm{NA})$ or $60 \times(1.4 \mathrm{NA})$ objectives, and an EMCCD camera (iXon X3 DU897, Andor Technology). Low-magnification images were collected on a Nikon AZ100 Multizoom with AZ Plan Fluor $2 \times$ and $4 \times$ objectives, a Nikon DS-FilC camera and NIS Elements software. The OE thickness, apoptosis, and adenoviral infection rates were quantified using a minimum of three mice per genotype/treatment group. Images were taken from the dorsal-medial, dorsal-lateral, ventralmedial, and ventral-lateral regions of each section and a minimum of 10 sections per mouse were examined from across the rostral-caudal extent of the olfactory epithelium. In each image, OE thickness was measured from the OE basal lamina to apical surface and averaged for each genotype/treatment. To quantify apoptosis, the number of cleaved caspase-3positive cells per millimeter of $\mathrm{OE}$ was determined from each image and averaged for each genotype/treatment. Adenoviral infection rates were quantified as the number of positive cells per millimeter of $\mathrm{OE}$ from control (Ift $88^{\text {osnWT }}$ ) mice. To quantify glomerular cross-sectional area and corrected total cell fluorescence for tyrosine hydroxylase immunostaining a minimum of three mice per genotype/treatment were used. Images were taken from three locations across the rostral-caudal axis of the OB for each animal (rostral, middle, and caudal), at approximately the same rostral-caudal OB locations across all animals. The cross-sectional area and corrected total cell fluorescence for tyrosine hydroxylase immunostaining was calculated for every glomerulus in each section using a modified version of the method by McCloy et al. (2014). Images were processed and glomerular cross-sectional area as well as fluorescence intensity was quantified using NIH ImageJ software (https://imagej.nih.gov/). Images were assembled using Adobe Photoshop CS. Data expressed as mean \pm SEM.

Whole-mount and coronal section X-gal staining. Mice were deeply anesthetized with an intraperitoneal injection of xylazine $(100 \mathrm{mg} / \mathrm{kg})$ and ketamine $(10 \mathrm{mg} / \mathrm{kg})$, transcardially perfused with $4 \%$ paraformaldehyde (PFA) in $1 \times$ PBS, decapitated, and their heads were postfixed in $4 \%$ PFA on ice for $30 \mathrm{~min}$. For whole mounts, the dorsal aspect of the olfactory bulbs was exposed and tissue was subsequently washed in buffer A (100 mm phosphate buffer, $\mathrm{pH} 7.4,2 \mathrm{~mm} \mathrm{MgCl}_{2}$, and $5 \mathrm{~mm}$ EGTA) once for $5 \mathrm{~min}$, and once for $30 \mathrm{~min}$; followed by two washes ( $5 \mathrm{~min}$ each) in buffer B (100 mM phosphate buffer, pH 7.4, $2 \mathrm{mM} \mathrm{MgCl}_{2}, 0.01 \%$ sodium desoxycholate, and $0.02 \%$ Nonidet $\mathrm{P} 40$ ) at room temperature (Mombaerts et al., 1996). Tissue was then exposed to X-Gal $(1 \mathrm{mg} / \mathrm{ml})$ in buffer C (buffer $\mathrm{C}+5 \mathrm{~mm}$ potassium-ferricyanide, $5 \mathrm{~mm}$ potassiumferrocyanide) at $37 \mathrm{C}$ for $8-10 \mathrm{~h}$ (Mombaerts et al., 1996). Tissue was then rinsed with $1 \times$ PBS and imaged using a Nikon SMZ1270 stereomicroscope and a DS-Fi2 camera.

For coronal sections, postfixed tissue was decalcified, cryoprotected, embedded in OCT, and sectioned as described in the sections above.
Sectioned tissue was stained with X-Gal in the same manner as above and counterstained with neutral red (Mombaerts et al., 1996). Sections were imaged using a Nikon AZ100 multizoom (described above). Images were processed with NIH ImageJ and arranged using Adobe Photoshop CS. For both whole-mount and coronal sections, the number of glomeruli per half bulb was manually quantified. Data shown are mean \pm SEM.

Live en face confocal imaging and OSN cilia measurements. Mice were killed with $\mathrm{CO}_{2}$, rapidly decapitated, and the head was split along the cranial midline to expose the OE. Olfactory turbinates were dissected out in PBS, placed in a tissue chamber with stage (INUBG2A and UNIV2D35-2, Tokai Hit) and held in place with a tissue slice holder (Warner Instruments). Confocal $Z$-stack images $(0.15 \mu \mathrm{m}$ thick sections) of transduced OSNs were captured using a Nikon TiE-PFS-A1R confocal microscope (described above). Confocal images of individual or small groups of OSNs with a complete complement of cilia were identified based on adenoviral-mediated ectopic expression of MP-GFP or MP-mCherry. Individuals that were blind to the experimental treatment and mouse genotype completed quantification of the number of cilia per neuron and length of cilia using NIH ImageJ software. Cilia length and number/OSN are expressed as mean \pm SEM.

Live en face calcium imaging. Calcium imaging was done as described previously (Ukhanov et al., 2016). Both left and right turbinate and septal OE from 4-week-old animals were used for experiments 10-14 d after administering adenovirus encoding GCaMP6f. Mice were killed with $\mathrm{CO}_{2}$, rapidly decapitated, and the head was split along the cranial midline to expose the OE. Dissected tissues were kept on ice in a Petri dish filled with freshly oxygenated modified artificial CSF (ACSF) that contained the following (in mM): $120 \mathrm{NaCl}, 25 \mathrm{NaHCO}_{3}, 3 \mathrm{KCl}, 1.25 \mathrm{Na}_{2} \mathrm{HPO}_{4}, 1$ $\mathrm{MgSO}_{4}, 1.8 \mathrm{CaCl}_{2}, 15$ glucose, $305 \mathrm{mOsm}$ (adjusted with sucrose), $\mathrm{pH} 7.4$. For imaging, a small piece of the $\mathrm{OE}$ was mounted in the perfusion chamber (RC-23, Warner Instruments) with apical surface facing up. The chamber was transferred to the stage of upright microscope Zeiss Axioskop2F equipped with $40 \times$ water-immersion objective lens. Experimental solutions were applied directly to the field-of-view through a $100-\mu \mathrm{m}$-diameter needle made of fused silica and connected to the 9-channel Teflon manifold. Each perfusion channel was controlled by the electronic valves (VC-6, Warner Instruments). The calcium response presented as an increase of GCaMP6f fluorescence emanating from the knob and underlying dendrite, due in part to the broad focal plane. The tissue was illuminated using a standard eGFP filter cube BP490nm/535 $\mathrm{nm}$ (Omega Optical) and the emitted light was collected at $530 \mathrm{~nm}$ (BP $530 / 20$ nm, Omega Optical) by a 12-bit cooled CCD camera (ORCA R2, Hamamatsu). Both the illumination system (Lambda DG-4, Sutter Instruments) and image acquisition were controlled by Imaging Workbench 6 software (INDEC BioSystem). Calcium imaging experiments were performed during the light phase of the light/dark cycle (between 0800 and $1700 \mathrm{~h}$ ). Each knob/cell was assigned a region-of-interest (ROI) and changes in fluorescence intensity within each ROI were analyzed and expressed as the peak fractional change in fluorescent light intensity $F / F 0$ where $F 0$ is the baseline fluorescence before odorant application. For quantitative comparison, the peak amplitudes of the responses of different cells from each group were analyzed. To correct for individual variability of response magnitudes as previously reported, the peak amplitudes were additionally normalized to the saturated responses elicited by application of a mixture of $100 \mu \mathrm{M}$ IBMX (a phosphodiesterase inhibitor) and $10 \mu \mathrm{M}$ forskolin (Fsk; a selective agonist of adenylate cyclases) to robustly activate the cAMP signaling pathway present within the OSN knobs (Leinders-Zufall et al., 1998; Bozza et al., 2002; Feinstein et al., 2004; Peterlin et al., 2005, 2008). Application of IBMX/forskolin was also used to ensure the integrity of the cell in the absence of odor responses and identify total number of functional OSNs within a field.

3-isobutyl-1-methylxanthine (IBMX; I5879, Sigma-Aldrich) and $7 \beta$ acetoxy-8,13-epoxy- $1 \alpha, 6 \beta, 9 \alpha$-trihydroxylabd-14-en-11-one (Fsk, F3917, Sigma-Aldrich) were dissolved in ACSF with $0.1 \%$ DMSO. Odorants were delivered as aqueous solutions prepared in freshly oxygenated ACSF. A stock solution of a complex odorant mixture (Henkel-100, a gift from Hans Hatt, University of Bochum) was diluted 1:10 in DMSO and then mixed to final (reported) dilution with ACSF. All 100 odorants in the stock solution were at 
the same concentration (10 mm; Wetzel et al., 1999). ACSF supplemented with $0.1 \%$ DMSO, the odorant carrier, served as the control solution.

Analysis and graphical presentation of calcium imaging data were performed with Imaging Workbench 6 (INDEC), pClamp 10.7 (Molecular Devices), NIH ImageJ software, GraphPad Prism 7.

Electro-olfactogram. Mice were killed with $\mathrm{CO}_{2}$, rapidly decapitated, and the head was split along the cranial midline to expose the OE. Septal epithelium was removed to expose the olfactory turbinates and the intact hemisected preparation was mounted in Sylgard lined chamber. Vaporphase odor stimuli were generated as follows: a 1 M odorant stock solution was diluted 1:10 (in DMSO) and then mixed to the final (reported) dilution in ultrapure water. Single molecule odorants used: amyl acetate (AA; W504009, Sigma-Aldrich), acetophenone (ACP; \#A10701, SigmaAldrich), eugenol (Eug; \#119111000, Acros Organics), cineole (Cin; Y0000176, Sigma-Aldrich), 1-octanol (1-Oct; O4500, Sigma-Aldrich), and hexanal (Hex; 115606, Sigma-Aldrich). Ultrapure water supplemented with $0.1 \%$ DMSO, the odorant carrier, served as the control/ blank solution. Odorants were delivered from a sealed $100 \mathrm{ml}$ glass bottle via a picospritzer controlled by pClamp software v9.2 (Molecular Devices) as a $100 \mathrm{~ms}$ pressurized pulse injected into a continuous stream of humidified air flowing over the tissue. Electrodes (1-3 M $\Omega$ ) were made from borosilicate glass capillaries $(\mathrm{OD}=1.50 \mathrm{~mm}$, ID $=1.16 \mathrm{~mm}$; G85150T-3, Warner Instruments). Glass capillaries were pulled to a $\sim 2$ $\mu \mathrm{m}$ tip with a taper of 3-4 $\mathrm{mm}$ and filled with $0.5 \%$ SeaPlaque agarose (Lonza) in modified Ringer's solution (in mM: $135 \mathrm{NaCl}, 5 \mathrm{KCl}, 1 \mathrm{CaCl}_{2}$, $1.5 \mathrm{MgCl}_{2}$, and 10 HEPES, pH 7.4). Electro-olfactogram (EOG) recordings were performed during the light phase of the light/dark cycle (between 0800 and $1700 \mathrm{~h}$ ). EOG responses to odor pulses were recorded from turbinates II and IIb using a MultiClamp 700A amplifier controlled by pClamp software. The health of the hemi-section was monitored overtime based on EOG responses to intermittently delivered pulses of pure AA. Recordings were terminated if the responses became increasingly variable and lost reproducibility across the recording duration. Tissues were allowed 3 min between subsequent odor deliveries to reduced adaptation of the EOG response to a given odorant.

EOG responses were measured as the maximal peak amplitude from the pre-pulse baseline using Clampfit software (Molecular Devices). Data were normalized to the mean response to pure amyl acetate in wild-type littermate control mice. All data are expressed as normalized mean \pm SEM.

Open-field maze behavioral assay. The four-quadrant behavior chamber was designed to the same specifications as previously described by Root et al. (2014). Briefly, the custom-built behavioral chamber was an enclosed arena with air from each corner flowing toward to the center and exiting via an outlet in the center of the floor of the arena. The outlet was covered by a perforated polypropylene insert. Airflow was pumped into each quadrant at a rate of $150 \mathrm{ml} \cdot \mathrm{min}^{-1}$ via gas-mass flow controllers (model GFC17, Cole-Parmer) and exited the chamber via the floor outlet ( $1 \mathrm{inch}$ ) through a vacuum line at a rate of $700 \mathrm{ml} \cdot \mathrm{min}^{-1}$. The flow rate of the vacuum line was regulated by an in-line flow controller (model GR10510SVV, Key Instruments). As described by Root et al. (2014), the behavior chamber is symmetrical in shape and was contained in a lightproof structure within a dark room to reduce possible bias due to spatial cues from outside the behavior chamber. Dual infrared lights (15-IL05, Cop Security) and camera (ICD-49 camera with an infrared lens, Ikegami) mounted above the chamber tracked and recorded the animals' behavior in real-time, at a rate of $10 \mathrm{~Hz}$, using EthoVision XT9 software (Noldus). Behavior was analyzed offline using EthoVision software and GraphPad Prism v7.

OMPCre; Ift $88^{F / F}$ mice and their wild-type littermates were maintained in group-housed conditions on static housing racks with 12:12 h light/ dark schedule (lights on at $0700 \mathrm{~h}$ ) from wean (P21) to 8 weeks of age. Adult, 8-week-old mice received 3 consecutive days of intranasal adenovirus administration (described above) and were subsequently grouphoused on static housing racks on a reverse light cycle ( $12 \mathrm{~h}$ dark/light schedule, lights on at $1900 \mathrm{~h}$ ) until behavioral testing began 4 weeks later. Twelve hours before the start of testing, mice were brought to the experimental room to habituate and were maintained on reverse-light cycle and static housing conditions. All behavioral assays were completed dur- ing the dark phase of the dark/light cycle (between 0700 and $1900 \mathrm{~h}$ ). Mice were tested in the four-quadrant chamber once per day and responses to each odorant were assayed once per animal. Each behavioral trial lasted $20 \mathrm{~min}$, with constant airflow from each quadrant throughout the trial. First, mice were habituated to the four-quadrant chamber for 10 min. Odor was then introduced into one quadrant of the chamber by redirecting airflow (via a manual valve) through a $100 \mathrm{ml}$ glass bottle containing $1 \mu \mathrm{l}$ of pure 2-phenylethanol (2PE; 77861, Sigma-Aldrich) or $5 \mu \mathrm{l}$ of pure isopentylamine (IPA; \#126810, Sigma-Aldrich) on a small piece of Kimwipe for the remaining 10 min of the trial (Root et al., 2014). Odors were always delivered from the same quadrant and behavioral responses to investigative odors were always assayed before aversive odors. Additionally, to control for spatial bias, if mice exhibited a preference or avoidance to any quadrant $>25 \%$ from chance during the 10 min habituation phase (no odor), the trial was terminated and mice were retested another day. This occurred in $<10 \%$ of the mice examined in each group. The response to an odor during the first $5 \mathrm{~min}$ of the odordelivery phase of a trial was quantified as a performance index, which calculates the time spent in the odor quadrant as a percentage difference from chance Performance index $=(P-25) / 0.25$, where $P$ is the percentage time in the odor quadrant; Root et al., 2014].

Experimental design and statistical analysis. Both male and female mice were used throughout all experiments. Mice $\leq 4$ weeks old were considered juvenile, whereas mice $\geq 8$ weeks old were considered adult. Immunohistochemistry in coronal sections to characterize the $\mathrm{OE}$ of Ift $88^{\text {osnWT }}$ and Ift $88^{\text {osnKO }}$ mice were completed in P21 age mice. Quantification of OE thickness, cleaved caspase-3-positive OSNs (apoptosis), adenoviral infection rates, TH intensity, and glomerular cross-sectional areas were examined in mice age $\mathrm{P} 21$. For rescue of $\mathrm{TH}$ and glomerular area mice were adenovirally infected at age P7-P9 and examined at P21. A description of the number of mice used per treatment and the number of sections examined per mouse for all immunohistochemistry experiments can be found in the Immunohistochemistry section above. Statistical analyses used were as follows: OE thickness and apoptosis, Unpaired Student's $t$ test; TH intensity and glomerular area, Kruskal-Wallis nonparametric ANOVA with Dunn's post hoc pairwise comparisons.

For OSN cilia length and number quantification, mice age $\mathrm{P} 7-\mathrm{P} 9$ were infected with adenovirus and examined at age P21. The turbinates of three to five mice were examined per genotype/treatment group and 3-10 neurons per mouse were imaged. Statistical analyses comparing Ift $88^{\text {osnWT }}$ (WT), Ift $88^{\text {osnKo }}(\mathrm{KO})$, and Ift $88^{\text {osnKO}}$; rescue (Rescue) mice performed using ANOVA with Tukey's post hoc pairwise comparisons.

To examine the odor-induced calcium responses of individual neurons; 4-week-old mice were infected with adenoviral GCaMP6f and examined 10-14 d later. We examined 85 neurons across $13 \mathrm{OE}$ regions in $4 \mathrm{WT}$ mice, 121 neurons across $30 \mathrm{OE}$ regions in $8 \mathrm{KO}$ mice, and 29 neurons across 7 OE regions in 3 rescue mice. Calcium responses of WT, $\mathrm{KO}$, and Rescue mice across varying concentrations of odors were statistically examined using repeated measures two-way ANOVA with Tukey's post hoc. A Kruskal-Wallis nonparametric ANOVA with Dunn's post hoc pairwise comparisons was used to examine differences in the percentage of odor responsive OSNs.

Quantification of EOG responses were examined in juvenile mice at P21 after adenoviral infection at P7-P9, whereas adult (10-week-old) mice were examined 2 weeks after adenoviral infection at 8 weeks old. Differences in EOG responses for WT, KO, and Rescue mice across odors were examined using repeated measures two-way ANOVA with Tukey's post hoc pairwise comparisons.

Examination of OSN axon wandering and quantification of number of dorsal OB glomeruli was completed at four different ages. Juvenile mice received adenoviral infection at $\mathrm{P} 7-\mathrm{P} 9$ and were examined at either P21 or 8 weeks old. For adult treatment, 8 -week-old mice received adenoviral infection and were examined either 2 weeks (10 weeks old) or 4 weeks later (12 weeks old). For examination of lacZ-positive glomeruli in crosssections of the $\mathrm{OB}$, the entire rostral-caudal extent of the $\mathrm{OB}$ was sectioned and every section was examined in three mice per genotype/ treatment group. Statistical analyses performed using ANOVA with Tukey's post hoc pairwise comparisons to compare differences among WT, KO, and Rescue mice. 

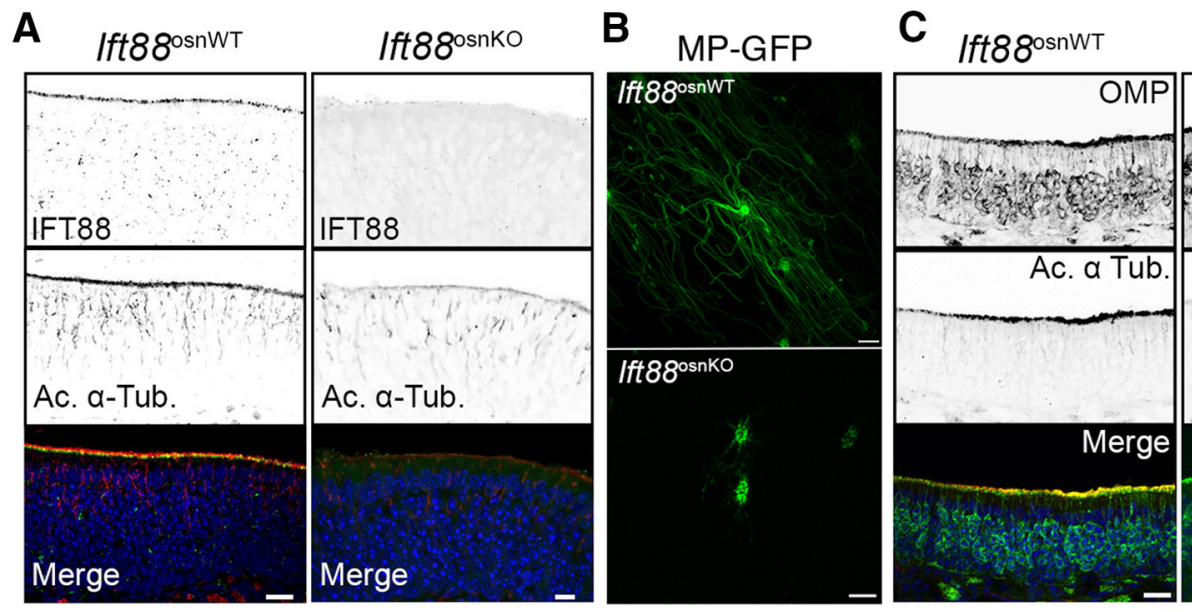

D
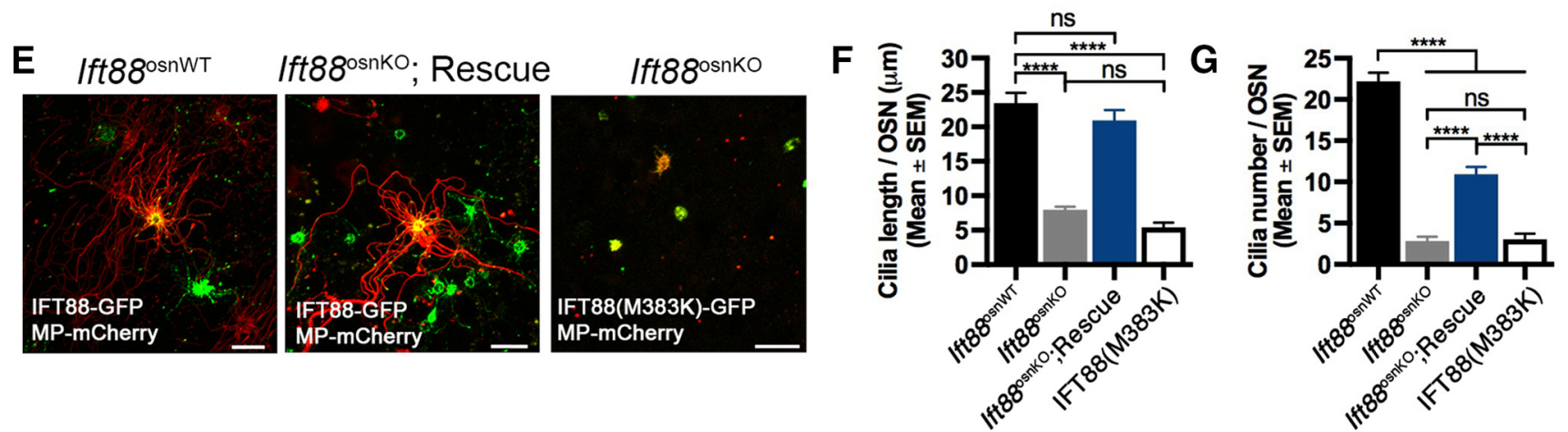

Figure 1. Gene therapeutic restoration of cilia morphology in Ift88 osnKo mutant OSNs. A, Confocal images of coronal sections through the 0 E in wild-type (Ift88 osnWT) and Ift88 osnk0 mice. Immunostaining of endogenous IFT88 and acetylated $\alpha$-tubulin (Ac. $\alpha$-Tub.) shows loss of IFT88 at the apical surface of the 0 E in Iff8 $88^{\text {osnK0 }}$ mice leading to a loss of cilia, indicated by a decrease in Ac. $\alpha$-Tub. B, En face confocal images of OSNs ectopically expressing a lipid anchored GFP (MP-GFP), which labels the full length of the cilia membrane. Ift88 $8^{\text {osnko }}$ mice exhibited a loss of cilia compared with WT mice. C, Immunostaining of coronal section of the OE for mature OSNs and cilia using olfactory marker protein (OMP) and Ac. $\alpha$-Tub, respectively. Ift88 osnK0 mice exhibited loss of cilia but not mature OSNs. D, Loss of cilia in Ift8 ${ }^{\text {osnk0 }}$ mice, as shown by loss of Ac. $\alpha$-Tub, did not induce apoptosis (cleaved caspase-3-positive olfactory cells; arrowheads). $\boldsymbol{E}$, $\boldsymbol{F}$, Cilia lengths in Ift88 ${ }^{\text {osnk0 }}$ mice are reduced compared with WT mice ( ${ }^{* * * *} p<0.0001 ; F_{(3,322)}=35.76, p<0.0001$; One-way ANOVA). Ectopic expression of wild-type IFT88-GFP in Ift88 ${ }^{\text {snkK0 }}$ mice completely restored cilia length to WT levels (ns, not significant; $p=0.6408$ ). Intranasal delivery of adenoviral IFT88(M383K)-GFP ((IFT88(M383K)), a nonfunctional human point mutation in IFT88, did not restore cilia length compared with WT mice $\left.{ }^{* * * *} p<0.0001\right)$ and were not different from Ift88 ${ }^{\circ \text { osnko }}$ cilia lengths (ns, $\left.p=0.6605\right)$. E, G, Ectopic expression of wild-type IFT88-GFP in Ift88 ${ }^{\circ \text { snkK0 }}$ mice partially restored cilia number compared with WT mice $\left(F_{(3,122)}=76.42, p<0.0001\right.$; One-Way ANOVA). The number of cilia on 0SNs from Ift $88^{\text {osnk0 }}$; rescue mice was increased above that of Ift8 $8{ }^{\text {osnKo }}$ mice $\left.{ }^{* * * *} p<0.0001\right)$ but not restored to that of Ift88 ${ }^{\text {osnWT }}$ mice $(* * * * 00.0001)$. Ectopic expression of IFT88(M383K)-GFP ((IFT88(M383K)) did not restore cilia number to WT values in Ift88 ${ }^{\text {osnK0 }}$ mice $\left({ }^{* * * *} p<0.0001\right)$ and were not different from Ifft8 ${ }^{\text {osnKo }}$ cilia number $(\mathrm{ns}, p=0.9978) . \boldsymbol{F}, \mathbf{G}, \mathrm{WT}=9$ neurons from 3 mice; $\mathrm{KO}=62$ neurons from 3 mice; Rescue $=34$ neurons from 3 mice; M383K-GFP $=21$ neurons from 3 mice. Lipid anchored mCherry (MP-mCherry) labeled the cilia membrane and was an inert marker of the full length of cilia. Values represent mean \pm SEM. Scale bars: $A, C, D, 20 \mu \mathrm{m} ; \boldsymbol{B}, E, 10 \mu \mathrm{m}$

For open-field maze behavior, 8-week-old mice received adenoviral infection and were examined for behavioral responses to IPA and 2PE 4 weeks later (12 weeks old). Statistical analyses to compare differences among treatments performed using ANOVA with Tukey's post hoc pairwise comparisons. One sample $t$ tests were performed on $\mathrm{KO}$ mice to verify significance from zero, to differentiate between complete loss or severe reduction in odor-guided behavior.

All values reported as mean \pm SEM. For all statistical analysis $\alpha=0.05$. Statistical analyses were performed using GraphPad Prism v7.

\section{Results}

Deletion of Ift88 in olfactory sensory neurons causes loss of olfactory cilia

To examine the consequences of olfactory-specific loss of Ift 88 in mature OSNs we generated tissue-specific Ift 88 knock-out mice (Ift $88^{\text {osnKO }}$ ). Mice containing floxed Ift $88^{f l / \Delta}$ (the $\Delta$ allele has exons 4-6 deleted from Ift88; Haycraft et al., 2007) were crossed with mice containing the OMP-Cre allele (Li et al., 2004), which express Cre recombinase specifically in mature OSNs. Littermate mice lacking the OMP-Cre allele were used as wild-type controls (Ift $88^{\text {osnWT }}$ ). In Ift $88^{\text {osnWT }}$ mice, immunostaining of IFT88 and acetylated $\alpha$-tubulin, which labels ciliary microtubules, shows colocalization of the fluorescent signal at the apical surface of $\mathrm{OE}$ (Fig. 1A). However, in Ift $88^{\text {osnKO }}$ mice both IFT88 and Ac. $\alpha$-Tub immunolabeling at the apical surface were largely absent, highlighting the loss of cilia on OSNs (Fig. 1A). The extent of cilia loss on individual OSNs of Ift $88^{\text {osnKO }}$ mice was assayed using live en face imaging of the OE adenovirally transduced with a lipid anchored GFP (MP-GFP; Fig. 1B). Despite the loss of cilia, the overall structure of the nasal mucosa was not significantly impacted. The loss of olfactory cilia in Ift $88^{\text {osnKO }}$ mice did not cause overt degeneration of the OE, as olfactory marker protein (OMP) immunostaining and the overall thickness of the OE were unchanged (OE thickness: Control mean $=83.6 \pm 3.2 \mu \mathrm{m}, n=9$; Ift $88^{\text {osnKO }}$ mean $=77.3 \pm 5.7 \mu \mathrm{m}, n=5$; Unpaired $t$ test; $t=$ 1.053, $\mathrm{df}=12, p=0.31$; Fig. $1 C$ ). Further, immunostaining for cleaved caspase-3, a marker of apoptosis, was not changed in Ift $88^{\text {osnKO }}$ mice ( $6.7 \pm 1.4$ cells $/ \mathrm{mm}, n=3$ ) compared with control Ift $88^{\text {osnWT }}$ mice $(7.0 \pm 1.8$ cells $/ \mathrm{mm}, n=3$; Unpaired $t$ test; $t=0.1364, \mathrm{df}=4, p=0.90$; Fig. $1 D)$. Together, these data show that genetic deletion of Ift88 in OMP-positive cells results in the 
loss of cilia on OSNs without a degradative loss of the nasal epithelium.

\section{Gene therapy restores olfactory ciliation and peripheral odor detection}

Given the reduction in cilia length and number in the mature OSNs of Ift $88^{\text {onnKO }}$ mice, we examined whether it is possible to restore normal ciliation on these OSNs. To rescue the loss of cilia we used an adenoviral IFT88-GFP fusion protein that we have previously shown to restore ciliation in OSNs of mice with a hypomorphic mutation of Ift88 (McIntyre et al., 2012). Live en face imaging of OSNs in mice adenovirally infected with MPmCherry allowed us to examine the length and number of cilia on individual neurons. OSNs of Ift $88^{\text {osnKO }}$ mice exhibited a $66 \%$ decrease in cilia length $(8.0 \pm 0.5 \mu \mathrm{m} ; p<0.0001)$ and an $86.4 \%$ decrease in the number of cilia per OSN $(3 \pm 1 ; p<0.0001)$ compared with littermate control Ift88 ${ }^{\text {osnWT }}$ mice $(23.5 \pm 1.5$ $\mu \mathrm{m}$ and $22 \pm 1$, respectively; Fig. $1 E-G)$. Next, we examined the infection rate of adenoviral expression of IFT88-GFP in OSNs to determine the extent to which OSN ciliation may be rescued. Examination of coronal sections of the OE demonstrated that $16 \pm 3(n=3$; mean $\pm \mathrm{SEM})$ cells $/ \mathrm{mm}$ of OE were infected. Importantly, expression of IFT88-GFP in OSNs of Ift $88^{\text {osnKO }}$ mice fully restored cilia length compared with Ift8 $8^{\text {onnWT }}$ mice $\left(21.0 \pm 1.5 \mu \mathrm{m}, p=0.6408 ; F_{(3,322)}=35.76, p<0.0001\right.$, ANOVA) and increased the number of cilia per OSN above that of Ift88 ${ }^{\text {osnKO }}$ mice $\left(11 \pm 1 ; p<0.0001 ; F_{(3,122)}=76.42, p<\right.$ 0.0001 , ANOVA; Fig. $1 E-G$ ); demonstrating that it is possible to rescue olfactory ciliation in differentiated neurons that lack Ift88. Interestingly, ciliation was not restored in OSNs after adenoviralmediated ectopic expression of IFT88(M383K)-GFP, a point mutation of IFT8 8 that was previously identified in a human fetus with an MKS-like ciliopathy (McIntyre et al., 2012; Fig. 1E-G). Thus, providing support that the IFT88(M383K) point mutation is a functionally null allele and further evidence that OSNs remain primed to regrow cilia after adenoviral delivery of the wildtype Ift 88 gene.

We next assessed the capacity for gene therapy mediated cilia restoration on rescuing peripheral odor detection. This was measured at multiple levels of integration starting with individual neuronal responses to odors. We used live en face calcium imaging of OSNs adenovirally expressing GCaMP6f to measure odorevoked calcium responses in the olfactory knobs. Henkel-100, a mixture containing 100 different odor components (LeindersZufall et al., 1998; Wetzel et al., 1999; Feinstein et al., 2004; Peterlin et al., 2005, 2008), was used to increase probability of finding responsive OSNs. Application of increasing concentration of Henkel-100 evoked a dose-dependent calcium response in $55.1 \%$ of wild-type neurons (WT, $n=85$ neurons from 4 mice; Fig. $2 A-D$ ) relative to those activated by IBMX/forskolin (mixed at 10 and $100 \mu \mathrm{M}$ ). Loss of cilia in Ifts8 ${ }^{\mathrm{osnKO}}$ mice (KO, $n=121$ neurons from 8 mice) led to a dramatic decrease of the odor responsiveness of OSNs compared with control Ift $88^{\text {osnWT }}$ mice in raw $\left(F_{(6,856)}=3.33, p=0.003\right.$, two-way ANOVA $)$ and normalized $\left(F_{(6,696)}=25.55, p<0.0001\right.$, repeated-measures twoway ANOVA) peak amplitudes (Fig. $2 A-C$ ). This resulted in a significant right-ward shift of the dose-response and a dramatic decrease to $8.2 \%$ of odor-sensitive OSNs in the knock-out $\left(H_{2}=\right.$ $34.3, p<0.0001$, Kruskal-Wallis; $n=13 \mathrm{WT}, 30 \mathrm{KO}, 7$ rescue; Fig. $2 B-D$ ). To assay the rescue at the single-cell level, Ift $88^{\circ \text { onnO }}$ mice were coinfected with GCaMP6f and IFT88-IRES-MPmCherry, whereby measuring odor-evoked GCaMP6f responses in rescued OSNs. Rescue of Ift $88^{\text {osnKO }}$ OSNs $(n=29$ neurons from 3 mice) resulted in a complete recovery of the dosedependent response (Fig. $2 A-D ; p>0.05$ ), as well as the percentage of odor-sensitive OSNs compared with Ift $88^{\text {osnWT }}$ mice (Fig. $2 D ; 54.9 \%, p>0.9999)$.

Although individual neurons express single odor receptor alleles, odor stimulation of the $\mathrm{OE}$ recruits a population of neurons to generate an ensemble response. To measure the effect of cilia loss at the population level we performed EOG recordings, which measure the change in summated field potentials from populations of OSNs in response to odorant stimulation. Compared with controls, Ift $t 88^{\text {osnKO }}$ mice elicited greatly decreased responses to a concentration range of $\mathrm{AA}$, as well as to $10^{-3} \mathrm{M}$ concentration of several single odors $\left(F_{(16,64)}=3.335, p<\right.$ 0.0001 , repeated-measures two-way ANOVA; $n=4 \mathrm{WT}, 3 \mathrm{KO}, 4$ rescue mice; Fig. $2 E$ ). In agreement with the loss of odor detection in Ift $88^{\text {osnKO }}$ mice, we also observed a decrease in OSN synaptic activity, as represented by a loss in TH immunostaining intensity in juxtaglomerular cells (Baker et al., 1983) in the glomerular layer of the $\mathrm{OB}\left(\mathrm{H}_{2}=488, p<0.0001\right.$, Kruskal-Wallis; $n=3$ WT, $3 \mathrm{KO}, 3$ rescue; Fig. $2 \mathrm{~F}-\mathrm{H}$ ). We also observed a reduction in the cross-sectional area of OB glomeruli in Ift $88^{\text {osnKO }}$ mice $\left(\mathrm{H}_{2}=\right.$ $363.7, p<0.0001$, Kruskal-Wallis; $n=3$ WT, 3 KO, 3 rescue; Fig. $2 G, H$ ), indicating possible OSN axon targeting defects due to loss of OSN signaling (Zheng et al., 2000; Zou et al., 2007; Williams et al., 2017). Importantly, intranasal adenoviral administration of IFT88-GFP at age P7-P9 restored EOG responses to WT levels in P21 age mice ( $p>0.05$; Fig. $2 E)$, and partially rescued TH immunostaining intensity and glomerular area compared with Ift $88^{\text {osnKO }}$ mice $(p<0.0001)$, but not to wild-type levels ( $p<$ 0.0001; Fig. $2 G, H$ ). Together, these data show that gene therapy can restore individual OSN and OE population level responses, as well as synaptic activity despite only rescuing a subset of mature OSNs.

\section{Renewal of ciliation using gene therapy restores proper axon targeting in the $\mathrm{OB}$}

Beyond the olfactory periphery, sensory deprivation is known to cause significant changes in the $\mathrm{OB}$ (Zheng et al., 2000; Zou et al., 2004). With regards to ciliopathies, the global knock-out of BBS8 resulted in aberrant axon targeting of OSNs to multiple glomeruli (Tadenev et al., 2011). Therefore, we examined whether axon targeting is disrupted in our Ift $88^{\text {osnKO }}$ ciliopathy mouse model and whether we could rescue these deficits in young mice (P21) using gene therapy. To do this, we crossed mice expressing bicistronic transcription of tau-lacZ downstream of the M71 odorant receptor (M71-IRES-taulacZ) with OMPCre;Ift88 ${ }^{F / F}$ mice to produce M71iTL;OMPCre; Ift88 ${ }^{F / F}\left(\mathrm{M} 71-\right.$ Ift8 $\left.{ }^{\text {osn }}\right)$ reporter mice. We examined axon targeting and convergence to dorsal glomeruli in P21 age M71-Ift8 $8^{\text {osnWT }}$ and M71-Ift $88^{\text {onnKO }}$ mice using wholemount X-gal staining. In M71-Ift88 ${ }^{\text {osnWT }}$ mice, lacZ-expressing axons fasciculated and converged to a single glomerulus on the dorsal surface of the OB, while lacZ-expressing axons in M71Ift $88^{\circ \text { osnKO }}$ mice wandered and, in these mice, there was an increased glomerular number per $\mathrm{OB}\left(F_{(2,25)}=7.09, p=0.0036\right.$, ANOVA; $n=9$ WT, 10 KO, 9 rescue mice; Fig. $3 A, B)$. To determine whether these effects extended beyond the juvenile $\mathrm{OB}$, we expanded our observations to 8-week-old adult mice, when the OB is completely developed (Marks et al., 2006). In agreement with our observations in P21 mice, 8-week-old M71-Ift88 ${ }^{\text {osnKO }}$ mice exhibited decreased fasciculation and multiple glomeruli per OB $\left(F_{(2,40)}=17.87, p<0.0001\right.$, ANOVA; $n=18 \mathrm{WT}, 11 \mathrm{KO}$, 14 rescue mice; Fig. $3 C, D)$. Next, we examined whether intranasal delivery of IFT88-IRES-MP-GFP from age P7-P9 could restore 
A

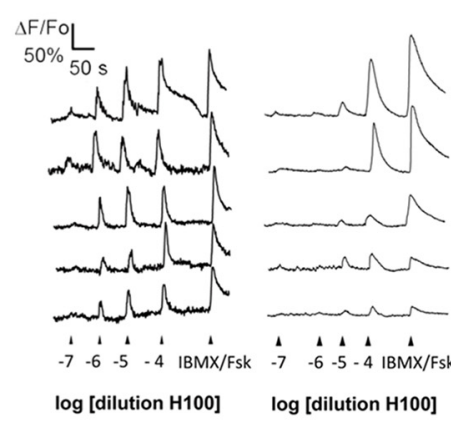

B

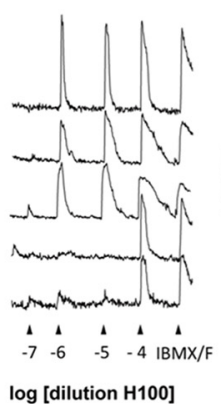

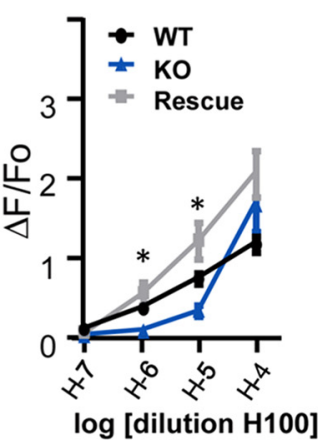

C

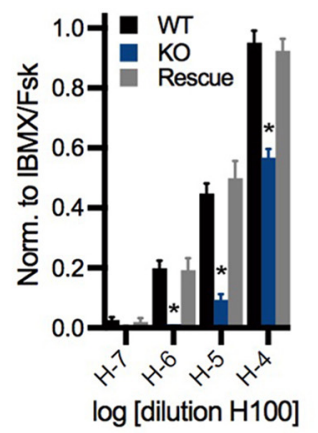

D

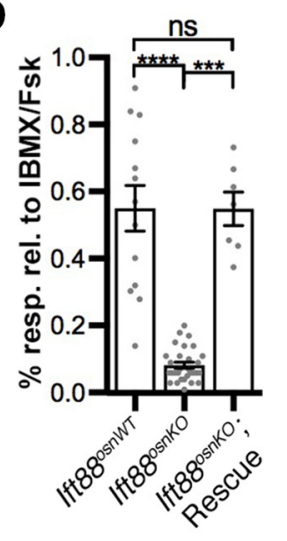

F

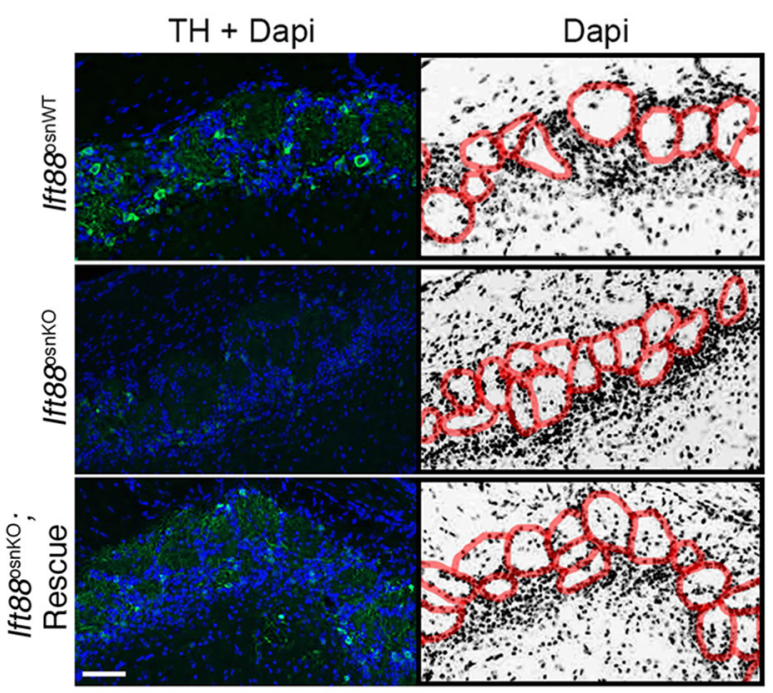

E

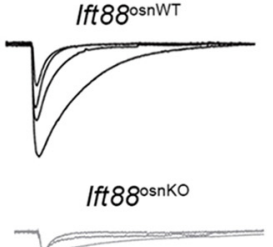

Ift88 osnko ; Rescue

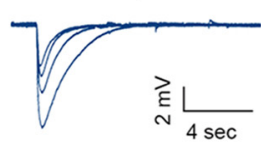

Ift88 osnWT

Ift88 $8^{\text {osnko }}$

Ift88 osnko; Rescue
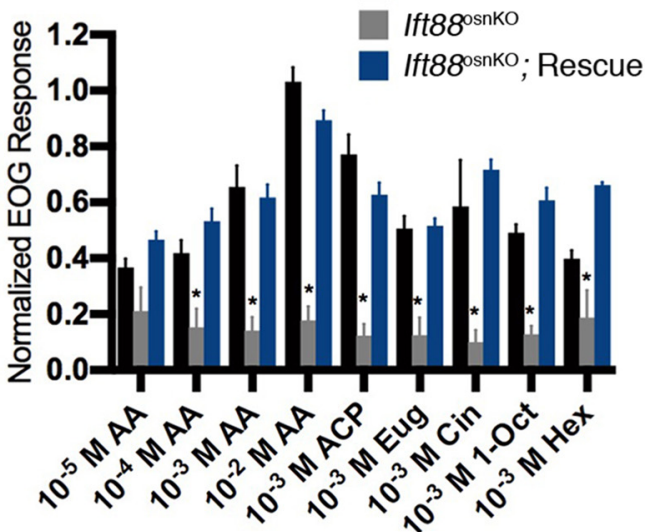

G
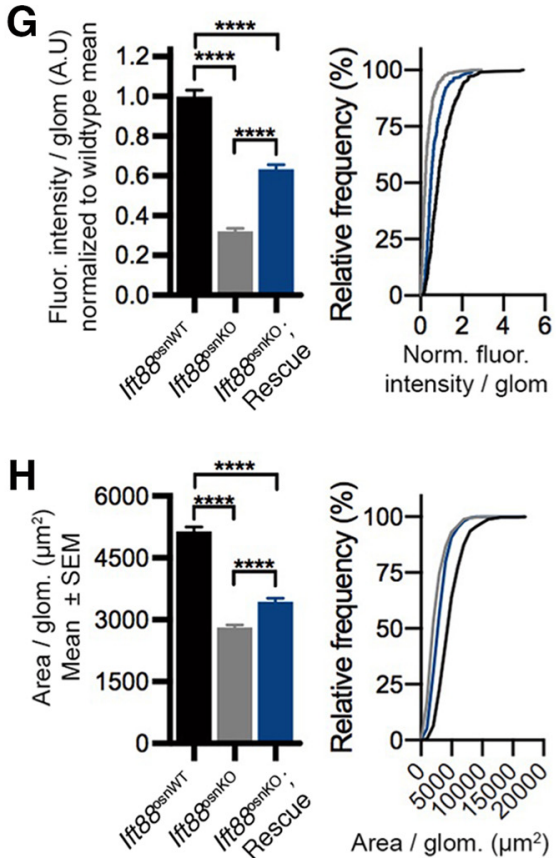

Figure 2. Gene therapeutic rescue of odor detection in Ift88 ${ }^{\text {osnKo }}$ mutant mice. $A, 0$ dor-evoked responses measured with ectopically expressed GCaMP6fin representative 0SNs from three animal

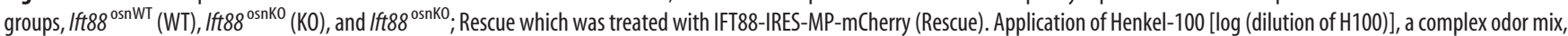
was followed by a mixture of IBMX and Fsk (100/10 $\mu \mathrm{m}$; IBMX/Fsk) to evoke a saturated response used for normalization. Stimuli were applied for $5 \mathrm{~s}$ at time indicated by black arrowheads below traces. Traces represent raw fluorescence corrected for the background and shown to the same scale. $\boldsymbol{B}$, Quantified mean raw peak amplitudes from animal groups $(n=85$ neurons in $4 \mathrm{WT}$ animals; KO group, $n=121$ neurons in $8 \mathrm{KO}$ animals; $n=29$ neurons in 3 Rescue animals). Adenoviral delivery of wild-type IFT88 restored dose-dependent responses in K0 mice (two-way ANOVA, $\left.F_{(6,856)}=3.33, p=0.003\right)$. Asterisk $\left(^{*}\right)$ denotes significant difference $(p \leq 0.001)$ for the treatment factor (i.e., WT, K0, Rescue) within a given concentration of Henkel-100. $C$, To correct for inherent variability of calcium data, odor responses were normalized to IBMX/Fsk response. Adenoviral delivery of wild-type IFT88 restored dose-dependent responses in K0 mice (repeatedmeasures two-way ANOVA, $\left.F_{(6,696)}=25.55, p<0.0001\right)$. Asterisk $\left(^{*}\right)$ denotes significant difference $(p \leq 0.0001)$ for the treatment factor (i.e., WT, K0, Rescue) within a given concentration of Henkel-100. D, Percentage of GCaMP6f-expressing 0SNs activated with the Henkel-100 odorant mixture (1:10,000 dilution) relative to 0SNs activated with a mixture of IBMX/Fsk was reduced in KO mice and restored in rescue mice (Kruskal-Wallis, $\mathrm{H}_{2}=34.3, p<0.0001$ ). The percentage of responding OSNs in KO mice was reduced compared with WT (Figure legend continues.) 

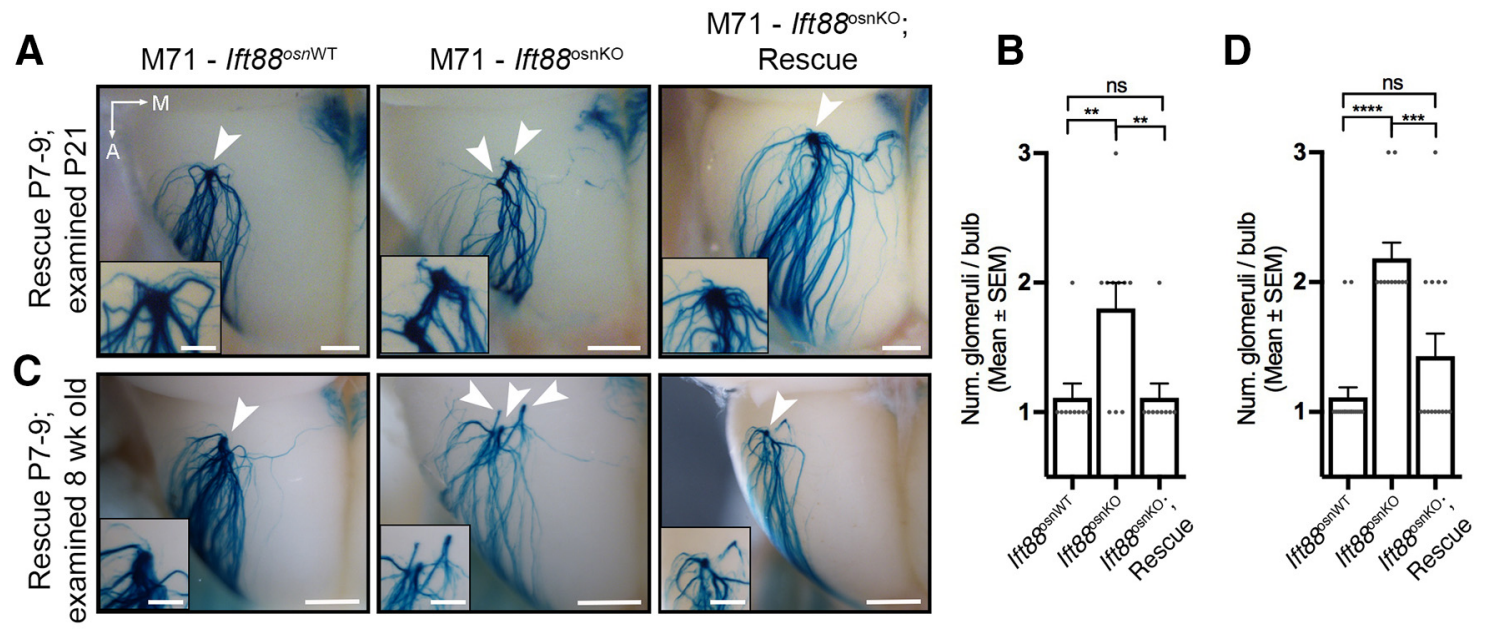

Figure 3. Restoration of axon targeting in juvenile Iff8 $88^{\text {osnK0 }}$ mutant mice after adenoviral gene therapy. The OR reporter mouse M71-IRES-tauLacZ was crossed with the 0MP-IFT88 mouse and axonal targeting of M71 OSNs was examined by whole-mount X-Gal staining in P21 and 8-week-old M71-Ift88 osnWT and M71-Ift88 ${ }^{\text {osnKo }}$ mice as well as M71-Ift88 ${ }^{\text {osnk0 }}$ mice that received intranasal delivery of adenoviral IFT88-IRES-MP-GFP from P7-P9 (M71-Ift88 onnK0; rescue). $\boldsymbol{A}$, Representative images of LacZ-positive axons on the dorsal surface of the olfactory bulb (0B) of P21 mice. $\boldsymbol{B}$, Quantification of the number of dorsal glomeruli per OB in P21 mice $\left(F_{(2,25)}=7.09, p=0.0036\right.$, ANOVA; $n=9$ WT, 10 K0, 9 rescue mice). The number of dorsal glomeruli in M71-Ift88 ${ }^{\text {snnK0 }}$ mice was significantly different from M71-Ift88 ${ }^{\text {osnWT }}\left({ }^{* *} p=0.0093\right)$ and M71-Ift88 ${ }^{\text {osnKo }}$ rescue $\left({ }^{* *} p=0.0093\right)$ mice. Intranasal delivery of adenoviral IFT88-IRES-MP-GFP restored the number of glomeruli in M71-Ift88 osnKo rescue to that of M71-Ift88 osnWT mice (ns, not significant; $p>0.9999)$. C, Representative images of LacZ-positive axons on the dorsal surface of the 0B of 8-week-old mice. $\boldsymbol{D}$, Quantification of the number of dorsal glomeruli per $\mathrm{OB}$ in 8-week-old mice $\left(F_{(2,40)}=17.87, p<0.0001\right.$, ANOVA; $n=18 \mathrm{WT}, 11 \mathrm{KO}, 14$ rescue mice). The number of dorsal glomeruli in M71-Ift88 ${ }^{\text {osnK0 }}$ mice was significantly different from M71-Ift88 ${ }^{\text {osnWT }}(* * * *<0.0001)$ and M71-Ift88 ${ }^{\text {osnK0 }}$ rescue $\left({ }^{* * *} p=0.0008\right)$ mice. Intranasal delivery of adenoviral IFT88-IRES-MP-GFP restored the number of glomeruli in M71-Ift88 osnKo ${ }^{2}$ escue to that of M71-Ift8 $8^{\text {osnWT }}$ mice (ns, $\left.p=0.1534\right)$. Insets show glomeruli indicated by arrowheads. Scale bars: $A, 500 \mu \mathrm{m}$, inset, $100 \mu \mathrm{m}$; C, $1000 \mu \mathrm{m}$, WT inset, $100 \mu \mathrm{m}, \mathrm{K} 0$ and rescue inset, $300 \mu \mathrm{m}$.

axonal targeting in the OB. LacZ-positive axons on the dorsal surface of the OB of IFT88-IRES-MP-GFP-treated M71Ift $88^{\text {osnKO }}$ mice exhibited fasciculated axons that converged to a single glomerulus in P21 mice (Fig. $3 A, B$ ) and persisted up to 8-week-old mice (Fig. 3C,D). Together, these data support previous findings that alterations in cilia-specific genes result in aberrant axon targeting (Tadenev et al., 2011) and demonstrate for the first time that intranasal adenovirus-mediated gene therapy, in the postnatal developing olfactory system, can restore OSN axon targeting to $\mathrm{OB}$ glomeruli.

(Figure legend continued.) $\left.{ }^{* * * *} p<0.0001\right)$ and rescue mice $\left({ }^{* * *} p=0.0002\right)$, whereas the percentage of responding $0 \mathrm{SN}$ s in WT and rescue mice were not significantly different (ns, $p>$ 0.9999). $\boldsymbol{E}$, Left, Representative EOG recordings from the Ifft8 $8^{\text {osnWT }}$, Ift88 osnko, and Ift88 osnko + IFT88-GFP (rescue) P21 mice in response to increasing concentrations of AA. Right, Quantification of $E O G$ responses to increasing concentrations of $A A$ and a single concentration $\left(10^{-3} \mathrm{M}\right)$ of ACP, Eug, Cineole (Cin), 1-0ctanol (1-0ct), and Hexanal (Hex; Interaction: $F_{(16,64)}=9.335, p<$ 0.0001 , repeated-measures two-way ANOVA). Asterisk $(*)$ denotes significant difference of treatment (compared with WT) within a given odor. $\boldsymbol{F}$, Representative confocal images of coronal olfactory bulb sections showing return of TH immunoreactivity (green) in rescued Ift88 ${ }^{\text {osnKO }}$ mice. Right, DAPI-stained coronal OB sections depicting individual glomeruli (red circles). Scale bar, $50 \mu \mathrm{m}$. G, Left, TH fluorescence intensity per glomerulus normalized to the average of Ift88 ${ }^{\text {osnWT }}$ mice (Kruskal-Wallis, $H_{2}=488, p<0.0001$ ). TH fluorescence was reduced in Ift88 ${ }^{\text {osnK0 }}$ mice compared with lft $88^{\text {osnWT }}$ mice $\left.{ }^{* * * *} p<0.0001\right)$. Ectopic expression of IFT88-IRES-MP-mCherry in OSNs increased TH fluorescence in rescue mice above Ift880snK0 mice $\left(^{* * * *} p<0.0001\right)$ but were still different from Ift88 ${ }^{\text {osnWT }}$ mice $\left(^{* * * *} p<\right.$ 0.0001). Right, Cumulative frequency distribution of the normalized TH fluorescence intensity of /ft8 $8^{\text {osnWT }}$, Ift $88^{\text {osnKO }}$ and Iff8 $88^{\text {osnKo; }}$; Rescue mice. $\boldsymbol{H}$, Quantification of olfactory bulb glomerular cross-sectional area in Ift88 osnWT, Ift88 osnKo, and Ift88 osnKo; Rescue mice (Kruskal-Wallis, $\left.\mathrm{H}_{2}=363.7, p<0.0001\right)$. Ectopic expression of IFT88-IRES-MP-mCherry in 0SNs increased glomerular area in rescue mice above Ift880snK0 mice $\left.{ }^{* * * *} p<0.0001\right)$ but were still different from Ift88 ${ }^{\text {osnWT }}$ mice $\left(^{* * * *} p<0.0001\right)$. Right-Cumulative frequency distribution of the cross-sectional area per glomerulus of Iff $88^{\text {osnWT }}$, Ift8 $88^{\text {osnKo }}$, and Iff8 $88^{\text {osnKo }}$; Rescue mice.

\section{Adenovirus-mediated restoration of sensory input rescues axon-targeting defects with delayed onset in adult $\mathrm{OB}$}

Whereas juvenile rescue of central bulbar defects persists as the olfactory system matures in up to 8 -week-old mice (Fig. 3), the rescue of adult animals would provide valuable information regarding the therapeutic window for treatment of ciliopathy related olfactory dysfunction. Therefore, we tested whether it was possible to rescue the aberrant axon targeting phenotype in a fully developed olfactory system using adenovirus-mediated gene therapy. First, we confirmed that peripheral odor detection could be restored in the adult using EOGs to measure olfactory sensitivity in Ift $88^{\text {osnKO }}$ mice. Compared with controls, 10-week-old Ift $88^{\text {onnKO }}$ mice elicited decreased dose-dependent responses to a range of amyl acetate concentrations and to a single concentration of several odors (Treatment factor: $F_{(2,90)}=26.5, p<0.0001$, repeated-measures two-way ANOVA; $n=6 \mathrm{WT}, 4 \mathrm{KO}, 3$ Rescue mice; Fig. 4A). Two weeks after intranasal adenoviral administration of IFT88-IRES-MP-GFP at 8-week-old, the rescued Ift $88^{\text {osnKO }}$ adult mice exhibited restored EOG responses to WT levels ( $p>0.05$; Fig. $4 A$ ). We subsequently examined axonal targeting and convergence to dorsal glomeruli in adult M71Ift $88^{\text {osnWT }}$ and M71-Ift $88^{\text {osnKO }}$ mice using whole-mount X-gal staining. LacZ-positive axons in M71-Ift88 ${ }^{\text {osnKO }}$ mice exhibited wandering and an increased number of glomeruli was observed in each mouse per bulb compared with controls $\left(F_{(2,36)}=15.74\right.$, $p<0.0001$, ANOVA; $n=20$ WT, 8 KO, 11 rescue mice; Fig. $4 B$ ). Two weeks after adenovirus-mediated expression of IFT88 (8 weeks old +2 weeks), defasciculation and supernumerary glomeruli persisted and remained greater in M71-Ift $88^{\text {osnKO }}$ mice than control mice $(p<0.0001)$ and indistinguishable from untreated M71-Ift $88^{\text {osnKO }}$ mice ( $p=0.7684$; Fig. $\left.4 B\right)$.

Despite the full restoration of EOG responses at 2 weeks in the adult, OSN axon targeting remained disrupted. We rationalized that an expression period of 2 weeks was insufficient for the res- 
cue of axonal targeting; therefore, extended our examination window to 4 weeks posttreatment of adult M71-Ift $88^{\text {osnKO }}$ mice with IFT88-IRES-MP-GFP (12-week-old). Interestingly, whole-mount X-gal staining in rescued mice showed a decrease in axon wandering, as well as a decrease in the average number of glomeruli per $\mathrm{OB}$ compared with M71-Ift88 ${ }^{\text {osnKO }}$ mice $\left(F_{(2,45)}=26.09, p<0.0001\right.$, ANOVA; $n=$ $21 \mathrm{WT}, 12 \mathrm{KO}, 15$ rescue mice), indicating a partial rescue of axon targeting (Fig. $5 A, B)$. To confirm that M71-positive glomeruli were representative of true glomeruli (termination of OSN axons in a glomerulus as denoted by periglomerular cells) and not just axonal aggregations, we performed X-gal staining on coronal sections of the $\mathrm{OB}$ and counterstained with neutral red. Adult (12-week-old) M71Ift $88^{\text {osnWT }}$ mice exhibited a single lacZpositive glomerulus in serial sections (Fig. $5 C$, top), whereas M71-Ift $88^{\text {osnKO }}$ mice showed multiple glomeruli and wandering axons that innervate neighboring glomeruli (Fig. 5C, middle). Moreover, 4 weeks after adult ( 8 weeks old +4 weeks) M71-Ift $88^{\text {osnKO }}$ mice were infected with adenoviral IFT88-IRES-MP-GFP, lacZpositive axons were observed terminating in a single glomerulus with few wandering axons (Fig. 5C, bottom). To ensure that the rescue of axon targeting was not limited to only M71 odorant receptor expressing OSNs, we conducted immunostaining for Olfr-1507 (MOR28) in serial coronal sections of age matched Ift $88^{\text {osnWT }}$, Ift $88^{\text {osnKO }}$, and IFT88-IRES-MP-GFP adenoviral-treated Ift $88^{\text {osnKO }}$ mice. As was observed with M71-expressing OSNs, MOR28-expressing OSNs of adult Ift $88^{\text {osnKO }}$ mice also exhibited multiple glomeruli and wandering axons that innervated neighboring glomeruli, which was restored 4 weeks postadult adenoviral-mediated gene rescue (Fig. $5 D)$.

Gene therapeutic restoration of peripheral ciliary function promotes rescue of olfactory-mediated behaviors In therapeutic terms, the return of peripheral odor detection and the consequent central rewiring in the olfactory bulb can be considered ancillary to the recovery of odor perception. To further examine the extent of which gene therapy can restore the spectrum of olfactory function, we explored odor-guided behaviors in adult mice, 4 weeks post-treatment when odorant detection and axonal pathfinding were sufficiently restored. We specifically examined the innate avoidance behavior to IPA (negative valence) and appetitive
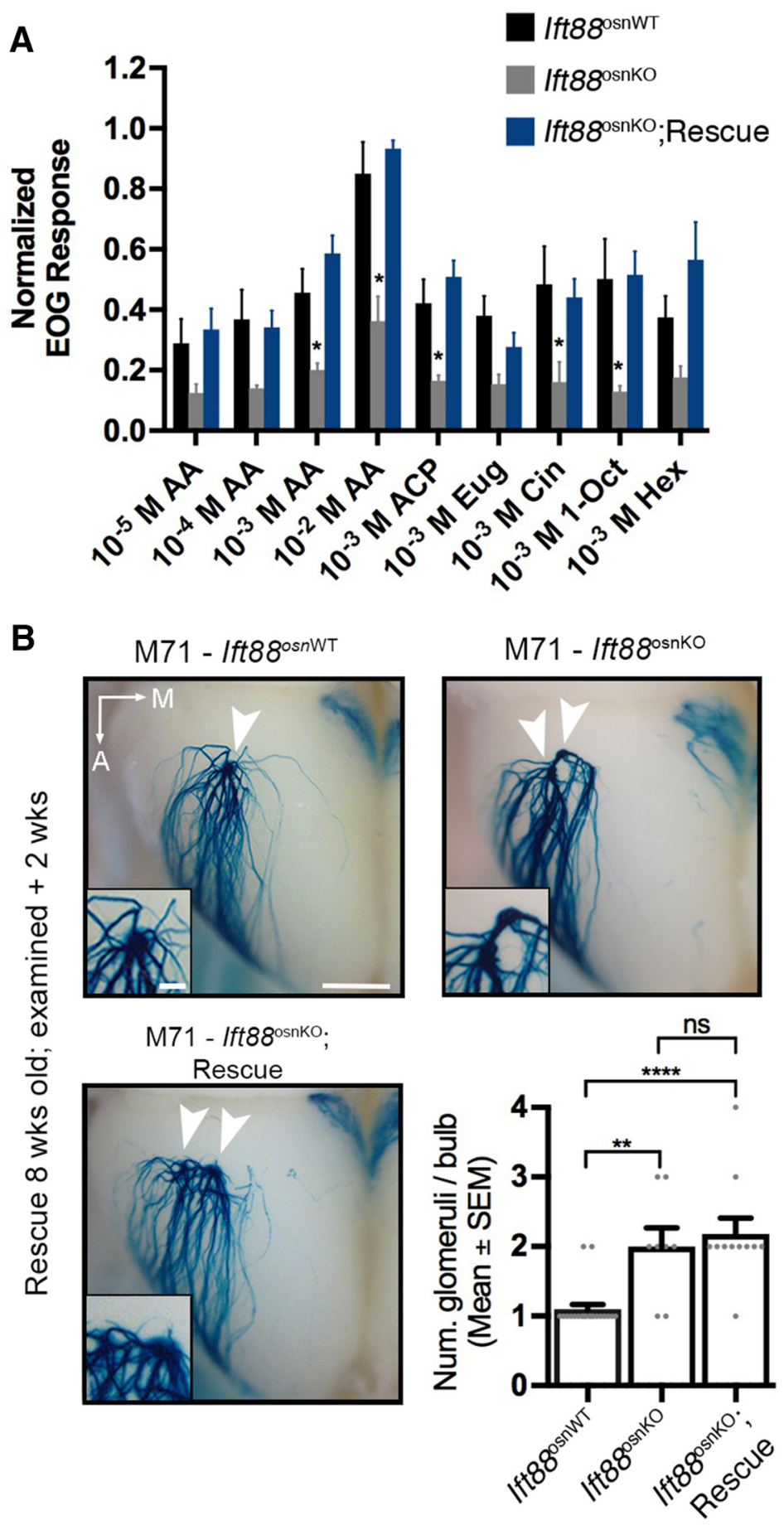

Figure 4. Gene therapy in the adult restored peripheral odor detection but not axon targeting 2 weeks post-treatment. To examine whether adenoviral gene therapy can restore olfactory function in adult mice we performed EOG recordings from the surface of the $0 \mathrm{E}$ in 10-week-old Ift88 ${ }^{\text {osnWT }}$, Ift8 $88^{\text {osnKo }}$, and Ift88 ${ }^{\text {osnKo }}+$ IFT88-IRES-MP-GFP rescued mice. Ift88 ${ }^{\text {osnKo; }}$; Rescue mice received intranasal delivery of IFT88-IRES-MP-GFP at 8-week-old for 3 consecutive days. $\boldsymbol{A}$, Quantification of EOG responses to increasing concentrations of AA and $10^{-3} \mathrm{M}$ of ACP, Eug, Cineole (Cin), 1-0ctanol (1-0ct), and Hexanal (Hex; Treatment factor: $F_{(2,90)}=26.5, p<0.001$, repeated-measures two-way ANOVA). Asterisk $\left(^{*}\right)$ denotes significant difference from wild-type. $\boldsymbol{B}$, Axon targeting was examined by whole-mount X-Gal staining in 10-week-old M71-lft88 ${ }^{\text {onnWT }}$, M71-lft8 ${ }^{\text {osnKo }}$, mice as well as and M71-Ift8 ${ }^{\text {osnK0 }}$ mice that received intranasal delivery of adenoviral IFT88-IRES-MP-GFP for 3 consecutive days at 8 weeks old (M71-Ift88 ${ }^{\text {osnKo }}$; rescue). Representative images of LacZ-positive axons on the dorsal surface of the OB. Bottom right, Quantification of the number of dorsal glomeruli per $\mathrm{OB}\left(F_{(2,36)}=15.74, p<0.0001\right.$, ANOVA; $n=20 \mathrm{WT}, 8 \mathrm{KO}, 11$ Rescue mice $)$. The number of dorsal glomeruli increased in M71-Ift88 ${ }^{\text {osnKo }}$ mice compared with M71-Ift88 osnWT mice $\left({ }^{* *} p=0.0015\right)$. Intranasal delivery of adenoviral IFT88-IRES-MP-GFP did not restore the number of glomeruli compared with M71-Ift88 ${ }^{\text {osnWT }}$ mice $\left({ }^{* * * *} p<0.0001\right)$ and was not different from M71-Ift88 ${ }^{\text {osnK0 }}$ mice (ns, not significant; $p=0.7684$ ). Insets show glomeruli indicated by arrowheads. Scale bars: $\boldsymbol{B}, 1000 \mu \mathrm{m}$, inset, $100 \mu \mathrm{m}$. 
A

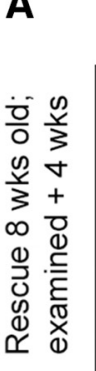

M71 - Ift88 osnko

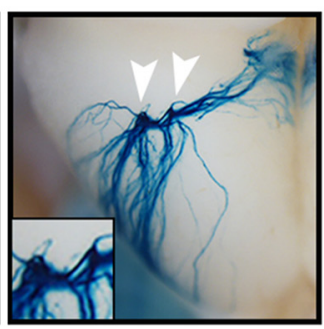

M71 - Ift88 osnKo.

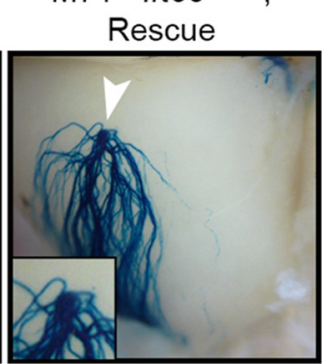

B

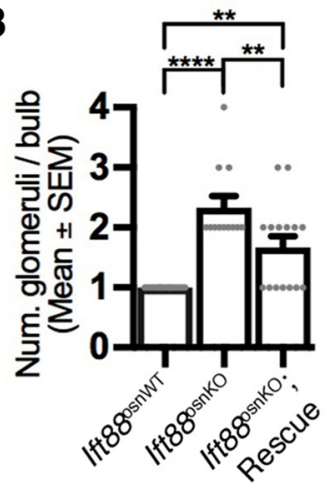

C

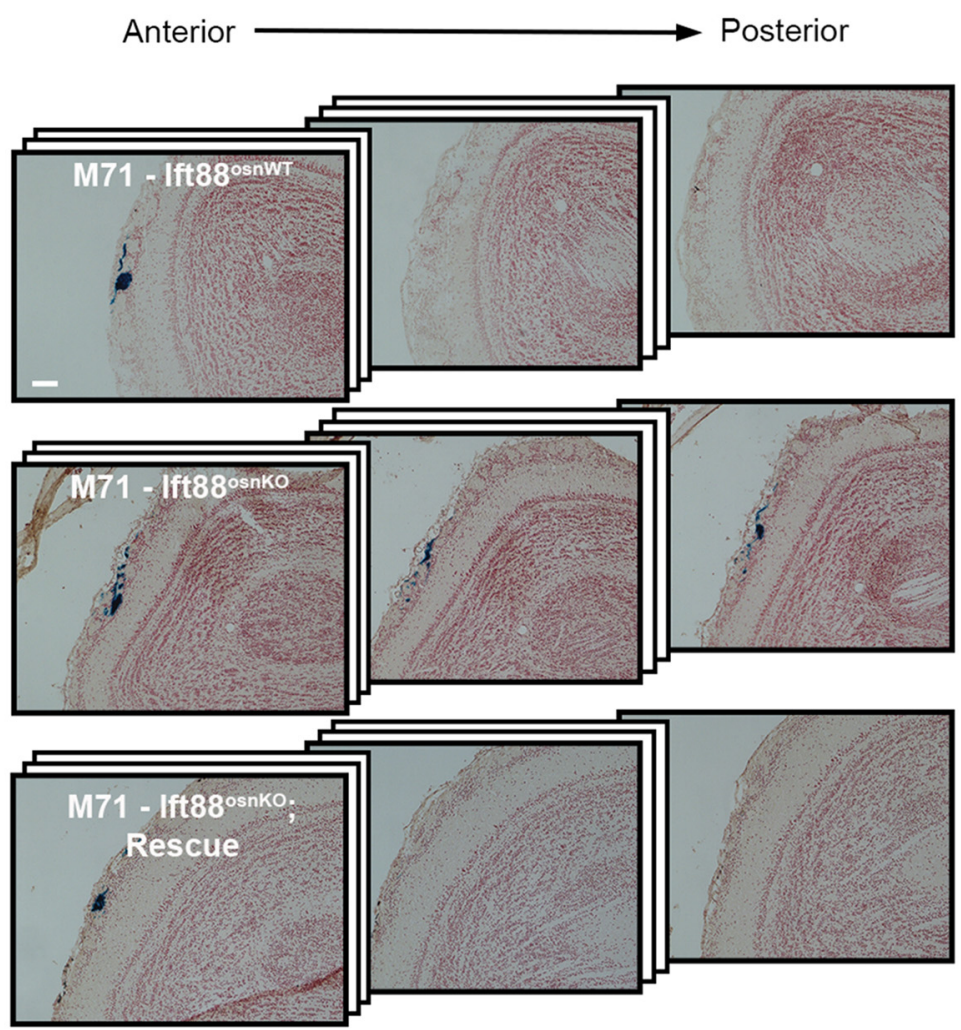

D Medial
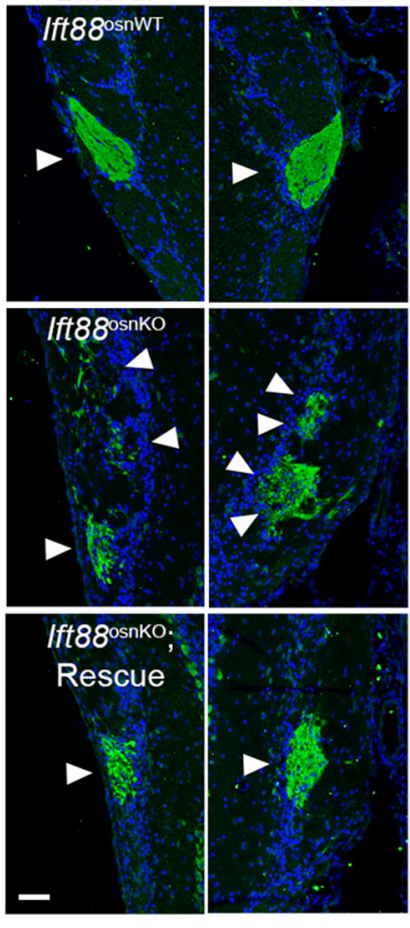

Figure 5. Restoration of axon targeting in adult Iff8 $88^{\text {osnK0 }}$ mutant mice 4 weeks after adenoviral gene therapy. M71-Ift88 osnWT and M71-Ift $88^{\text {osnK0 }}$ mice, as well as M71-Ift88 osnK0 mice that received intranasal delivery of adenoviral IFT88-IRES-MP-GFP for 3 consecutive days at 8-week-old (M71-Ift88 osnk0; Rescue). $\boldsymbol{A}$, Axon targeting was examined by whole-mount X-Gal staining. Representative images of LacZ-positive axons on the dorsal surface of the $O B$ show that olfactory sensory neuron axon targeting was partially rescued 4 weeks after gene therapy. Insets show glomeruli indicated by arrowheads. $B$, Quantification of the number of dorsal glomeruli per $\mathrm{OB}\left(F_{(2,45)}=26.09, p<0.0001\right.$, ANOVA; $n=21$ WT, $12 \mathrm{KO}, 15$ Rescue mice). The number of dorsal glomeruli increased in 12-week-old M71-Ift88 ${ }^{\text {osnK0 }}$ mice compared with M71-Ift88 osnWT mice ( $(* * * * 0<0.0001)$. Intranasal delivery of adenoviral IFT88-IRES-MP-GFP reduced the number of dorsal glomeruli in rescue (M71-Ift88 osnKo; Rescue) mice compared with M71-Ift88 ${ }^{\circ \text { snko }}$ mice $\left({ }^{* *} p=0.0048\right.$ ) but were still greater than the number of dorsal glomeruli in M71-Ift88 osnWT mice $\left({ }^{* *} p=0.0012\right)$. C, The OBs of M71-Ift88 ${ }^{\text {osnWT }}$, M71-Ift88 ${ }^{\text {osnKO }}$, and M71-Ift88 ${ }^{\text {osnKO }}$; Rescue mice were sectioned in their entirety from anterior to posterior, X-Gal stained and counterstained with neutral red to label nuclei. Representative images of coronal sections of the $O B$ at the same location along the anterior-posterior axis show that intranasal delivery of IFT88-IRES-MP-GFP (M71-Ift88 osnko; rescue) restored axon targeting to a single glomerulus in M71 odorant-expressing olfactory sensory neurons. D, To confirm that restoration of axon targeting was not limited to only M71-expressing neurons we immunostained coronal sections of the OB of 12-week-old Ift88 ${ }^{\text {onnWT }}$, Ift88 ${ }^{\text {osnKO }}$, and Ift88 osnKo + IFT88-IRES-MP-GFP rescued mice (rescued at 8 weeks old) for Olfr1507 and counterstained nuclei with DAPI. Representative images show intranasal gene therapy restoring axon targeting of Olfr1507-expressing olfactory sensory neurons in both the lateral and medial glomerulus in adult mice. Arrowheads denote axon convergence into a glomerulus. Scale bars: $A, 1000 \mu \mathrm{m}$, inset, $100 \mu \mathrm{m} ; \mathbf{C}, 100 \mu \mathrm{m} ; \mathbf{D}, 50 \mu \mathrm{m}$.

behavior to $2 \mathrm{PE}$ (positive valence) using a four-quadrant openfield behavioral assay (Root et al., 2014). IPA and 2PE have previously been shown to elicit aversive and appetitive behavioral responses, respectively (Dewan et al., 2013; Root et al., 2014). Aversive and appetitive responses were quantified using a performance index (PI) that calculates the percentage difference from chance occupancy in the odor quadrant (see Materials and Methods; Root et al., 2014). Negative PI values represent aversion to the odor, whereas positive PI values represent an appetitive re- sponse to the odor. In the absence of odor, mice explored all quadrants of the chamber equally, showing no bias to a given quadrant (Fig. 6A). In adult Ift $88^{\text {osnWT }}$ mice, IPA elicited robust avoidance behavior $(-56.7 \pm 3.47 ; n=17)$ to the odor delivery zone (Fig. $6 B, C$ ). In comparison, Ift $88^{\text {osnKO }}$ mice demonstrated a significant reduction in IPA-dependent aversive responses $\left(-16.57 \pm 6.58 ; n=10 ; F_{(2,37)}=20.33, p<0.0001\right.$, ANOVA $)$, but not a complete loss (one-sample $t$ test; $t=2.51, \mathrm{df}=9, p=$ 0.0330; Fig. $6 \mathrm{~B}, \mathrm{C}$ ). Similarly, Ift $88^{\text {osnWT }}$ mice exhibited robust 

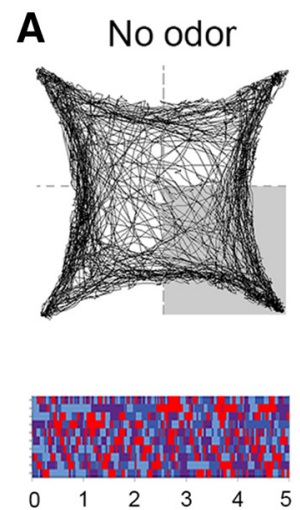

B
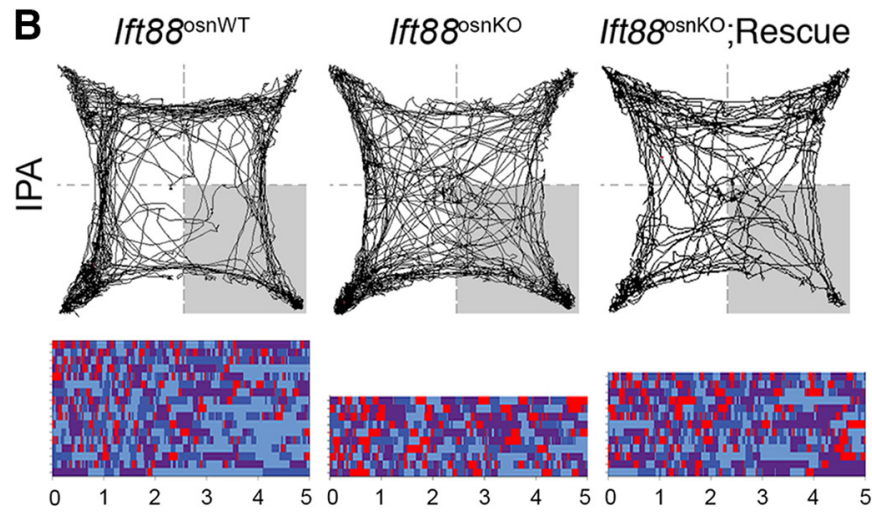

Time (min)

D

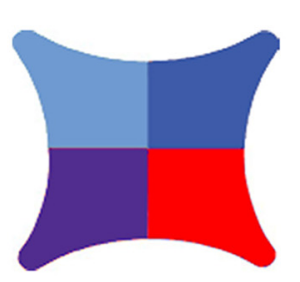

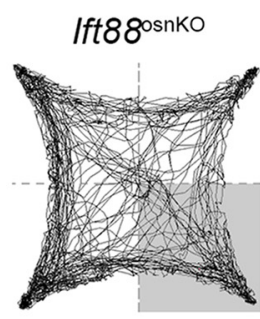
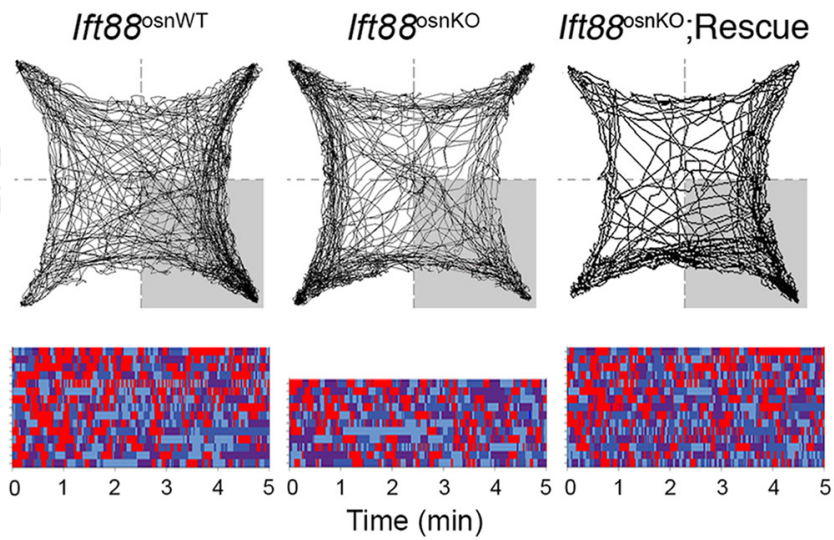

C

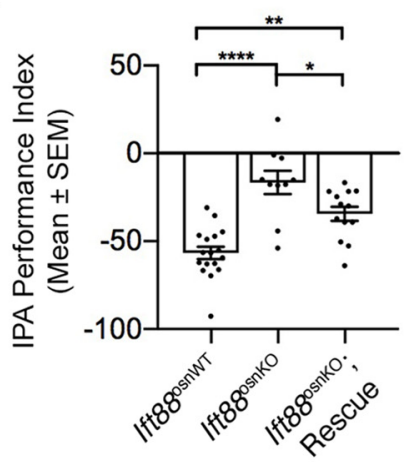

$\mathbf{E}$

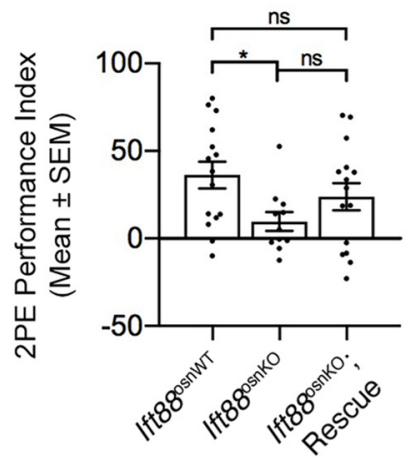

Figure 6. Gene therapy restored aversive and appetitive odor-guided behaviors in adult Ift8 ${ }^{\text {osnk0 }}$ mutant mice 4 weeks post-adenoviral delivery. Odor-guided behaviors were examined in Ift88 osnWT, Ift88 ${ }^{\text {osnKo }}$, and Ifft8 ${ }^{\text {osnKo }}+$ IFT88-IRES-MP-GFP rescued mice (rescued at 8 weeks old) using an open field, four-quadrant behavioral chamber at 12 -week-old (4 weeks post-rescue). $\boldsymbol{A}$, Representative trajectory plot of an Ift88 osnWT (wild-type) mouse exploring the chamber for 5 min when no odor was present. Raster plots below the trajectory show occupancy of each chamber quadrant over time $(5 \mathrm{~min})$ for 10 representative wild-type mice. Each horizontal row in the plot corresponds to a single animal tested. Bottom left, Color map of chamber quadrants for raster plots.

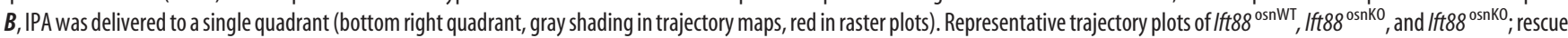
mice showing restoration of avoidance behavior 4 weeks after intranasal delivery of IFT88-IRES-MP-GFP in KO mice. Raster plots below traces show responses of all mice examined 4 weeks post-rescue. $C$, The average response to IPA quantified as a performance index that calculates the percentage difference from chance occupancy in the odor quadrant [performance index $=(P-$ $25) / 0.25$, where $P$ is the percentage time in the bottom right quadrant; Root et al., $2014 ; F_{(2,37)}=20.33, p<0.0001$, ANOVA]. Avoidance of IPA is reduced in Ift88 osnKo (****p $<0.0001$ ), and

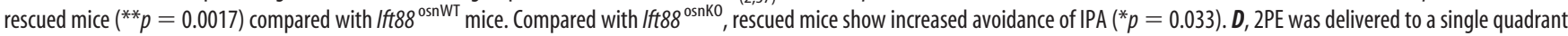

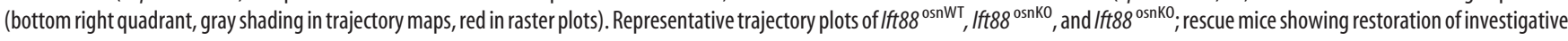
behavior 4 weeks after intranasal delivery of IFT88-IRES-MP-GFP in K0 mice. Raster plots below traces show responses of all mice examined 4 weeks post-rescue. $\boldsymbol{E}$, The average response to 2 PE quantified as a performance index $\left(F_{(2,38)}=3.044, p=0.05\right.$, ANOVA). Responses to $2 \mathrm{PE}$ are reduced in $/ f t 88^{\text {osnKo }}\left({ }^{*} p=0.0473\right)$ compared with $/ f t 88^{\text {osnWT }}$ mice, whereas responses in rescued mice are not different from $l f t 88^{\text {osnWT }}(\mathrm{ns}, p=0.4293)$ and $l f t 88^{\text {osnKo }}(\mathrm{ns}, p=0.3986)$ mice.

appetitive behaviors to $2 \mathrm{PE}(36.25 \pm 7.56 ; n=15)$, whereas 2PE-dependent appetitive responses in Ift $88^{\text {osnKO }}$ mice were significantly reduced $\left(9.75 \pm 5.44 ; n=11 ; F_{(2,38)}=3.044, p=0.05\right.$, ANOVA) with Ift88 ${ }^{\text {osnKO }}$ mice spending equal time in all four quadrants of the chamber (one-sample $t$ test; $t=1.79$, df $=10$, $p=0.1037$; Fig. $6 D, E$ ). Importantly, IFT88-IRES-MP-GFPtreated Ift $88^{\text {onnO }}$ mice (Ift $88^{\text {osnKO }}$ rescue; $-34.4 \pm 3.98 ; n=13$ ) exhibited increased aversive responses to IPA compared with Ift $88^{\text {osnKO }}$ mice $(p=0.033)$. A similar pattern was seen with rescue of appetitive behavior to $2 \mathrm{PE}$ as responses of Ift $88^{\text {osnKO; }}$ rescue mice $(23.84 \pm 7.76 ; n=15)$ were not different from Ift $88^{\text {osnWT }}$ mice $(p=0.4293)$.

\section{Discussion}

In the present study, we used a novel mouse model exhibiting an OSN-specific loss of cilia to examine the impact of ciliopathyinduced olfactory dysfunction beyond the OE, as well as the potential for gene therapeutic restoration of axonal pathfinding and odor-guided behaviors. We demonstrated that in vivo gene therapy can restore OSN cilia length and number in addition to odor- induced responses in individual neurons. Notably, this is the first report that in vivo gene therapy restores ciliopathy-induced OSN axon targeting defects in both the developing and established (adult) OB, as well as has the capacity to restore both aversive and appetitive odor-guided behaviors. This work highlights the potential for gene therapy to rescue olfactory function and odor perception in patients with ciliopathy-induced olfactory dysfunctions.

The OE may represent a therapeutically privileged tissue due to its accessibility and amenability to adenoviral and adenoassociated viral infections (Williams et al., 2017). Our noninvasive method induced ectopic gene expression in up to $15 \%$ of mature OSNs. Although adenoviral gene expression occurs quickly within the $\mathrm{OE}$ (within $10 \mathrm{~d}$ ) and is sustained for at least 1 month (McIntyre et al., 2012; Williams et al., 2017), our results are surprising because they show that rescue of a limited number of OSNs was sufficient to restore olfactory bulb axon targeting and odor-guided behaviors. It is important to note that infection rate is not uniform across the entire OE and the reported trans- 
duction efficiency is an average across all regions. Nonetheless, these observations are promising because the treatment achieved measurable restoration of olfactory sensitivity without necessitating high infection efficiency. We argue that a similar approach may translate to patients resulting in positive outcomes that would ultimately improve odor perception.

This work also raises an interesting biological question of the magnitude of primary synaptic input to the $\mathrm{OB}$ necessary to elicit course olfactory behaviors. We know that a significant fraction of the $\mathrm{OE}$ and the olfactory bulb can be lost while retaining olfactory function (Xu and Slotnick, 1999; Slotnick and Bodyak, 2002). We also know that activation of an individual glomerulus, a small subset of glomeruli, or subsets of mitral cells is sufficient to elicit behavioral responses in fine perceptual assays (Mouly et al., 1985; Mouly and Holley, 1986; Verhagen et al., 2007; Wesson et al., 2009; Smear et al., 2013). Additionally, the graded response amplitudes of individual glomeruli carry information about odor identity and intensity, which contributes to odor perception (Rubin and Katz, 1999; Wachowiak and Cohen, 2001; Bozza et al., 2004; Smear et al., 2013). These studies show that focal stimulation in healthy animals, either electrically or ontogenetically of a subset of neurons within intact circuits, can elicit fine olfactory behaviors. However, in the context of sensory deprivation due to loss of cilia, it is unknown to what degree of restoration is necessary to recover these fine behaviors. Comparison of our results with other work in the field may highlight differences between fine and course odor-guided behaviors. $K_{V} 1 \cdot 3^{-1-}$ mice exhibit decreased glomerular size and an increased number of glomeruli, similar to Ift $88^{\text {osnKO }}$ mice; however, $K_{V} 1.3^{-1-}$ mice also exhibit increased odor discrimination abilities (Fadool et al., 2004). Finer perceptual assays to measure odor discrimination, threshold detection, or adaptation, could not be performed in Ift $88^{\text {osnKO }}$ mice as they are severely olfactory impaired and cannot learn odorassociated tasks. The refinement of standard operant reward conditioning assays is required to address these specific questions. Nonetheless our work supports the notion that restoration of a limited number of OSNs can restore course olfactory behaviors.

Open field place-preference assays have been used successfully to examine odor-guided behaviors when peripheral olfactory input is perturbed. These course behavioral assays have shown the function of olfactory-specific and/or cilia-specific proteins. Genetic deletion of OSNs, olfactory signal transduction components, or channels required for synaptic activity, caused a reduction in appetitive and/or aversive behaviors. (Mandiyan et al., 2005; Kobayakawa et al., 2007; Zou et al., 2007; Weiss et al., 2011; Dewan et al., 2013). Additionally, ciliopathy mouse models $\left(B b s 2^{-l-}, B b s 4^{-1-}\right.$, and $B b s 1^{\text {M390R/M390R }}$ ) displayed olfactory deficits in the buried food behavior assay (Nishimura et al., 2004; Davis et al., 2007). However, the interpretation in changes to olfactory-mediated behaviors in these ciliopathy mouse models may be confounded by the loss of ciliation or ciliary function in other cell types in the brain. Using a model in which a ciliary gene was selectively disrupted in the principal sensory cells of the OE, as in the current study, is a necessary first step for assessing the contribution of OSN-specific sensory input to behavior in ciliopathy models. Interestingly, we also observed differences in the magnitude of rescue between aversive and appetitive behaviors. It is possible that this reflects differences in the central circuitry and sensory input associated with the behaviors, which has been observed in other studies (Li and Liberles, 2015; Muthusamy et al., 2017). Therefore, disruption of the appetitive behavior due to ciliopathy-induced sensory loss may necessitate an increased or higher infection efficiency to be restored.
The innate regenerative capacity of the olfactory system may provide an additional therapeutic advantage over other ciliated organ systems. The OE contains a population of active stem cells that regulate constitutive neurogenesis throughout life (Schwob et al., 2017). In addition, granule cells, the primary inhibitory interneurons of the $\mathrm{OB}$, also undergo turnover in rodents via migration of precursor cells along the rostral migratory stream from the subventricular zone (Alvarez-Buylla and GarcíaVerdugo, 2002). Examination of the OE in ciliopathy models studied to date has shown that loss of cilia on OSNs does not cause degeneration of the OE (Kulaga et al., 2004; Mcewen et al., 2007; Tadenev et al., 2011; McIntyre et al., 2012; Williams et al., 2017), likely due in part to the continual replacement of neurons and/or survival of the OSNs following ciliary loss. This contrasts with other sensory tissues including the retina, where ciliopathies such as BBS, exhibit progressive degeneration of photoreceptor cells (Fath et al., 2005; Azari et al., 2006; Gerth et al., 2008; Mockel et al., 2012). Due to this cell degeneration, gene therapy in the retina has focused on preventative treatment in young animals, with restoration of BBS gene function in immature photoreceptor cells leading to anatomical and functional repair (Hsu et al., 2017). In the current study, our data show that adenoviral gene replacement of IFT88 in both juvenile and adult mice restored odor detection, axon targeting, and odor-guided behaviors. Thus, demonstrating the capacity for both preventative and restorative therapies in the olfactory system.

The delayed onset for restoration of axon targeting in the adult olfactory bulb may reflect differences between $\mathrm{OE}$ and $\mathrm{OB}$ plasticity. Our work showed that it is possible to restore OE function, as well as OSN axon targeting in 8-week-old adult animals. However, whereas OE function was restored 2 weeks after ectopic gene delivery in adult mice, axon targeting in the $\mathrm{OB}$ was not restored until 4 weeks post-gene delivery. It is possible that full restoration of axon targeting with the return of sensory input requires a dynamic reciprocity between OSNs and olfactory bulb neurons (Cummings and Belluscio, 2010). It is also unclear whether recovery of adult $\mathrm{OB}$ axon targeting is a result of axonal pruning and rewiring of rescued OSN axons. In addition, it could include the contribution of newly emerged OSNs that correctly target their axons over this 4 week period. Importantly, it is also unknown whether correction of axon targeting defects is necessary or contributes to restoration of course odor-guided behaviors. Nevertheless, our data suggest that the therapeutic window for treating olfactory dysfunction extends beyond development and into adulthood. Future studies will need to investigate the precise mechanisms of this delayed recovery of OSN axon targeting in the adult animal.

In summary, our work is the first to demonstrate that ectopic adenoviral gene therapy has the potential to restore olfactory function from odor detection to odor perception. Moreover, gene therapy restores function in both the developing and adult olfactory system, suggesting a broad therapeutic window for treating olfactory dysfunction in ciliopathies. These findings, which highlight the therapeutic potential of in vivo gene therapy in ciliopathy-related olfactory dysfunction, are critical steps toward studies using patient relevant models and clinically approved vectors required to translate to a clinical population.

\section{References}

Alvarez-Buylla A, García-Verdugo JM (2002) Neurogenesis in adult subventricular zone. J Neurosci 22:629-634. CrossRef Medline

Azari AA, Aleman TS, Cideciyan AV, Schwartz SB, Windsor EA, Sumaroka A, Cheung AY, Steinberg JD, Roman AJ, Stone EM, Sheffield VC, Jacobson 
SG (2006) Retinal disease expression in Bardet-Biedl syndrome-1 (BBS1) is a spectrum from maculopathy to retina-wide degeneration. Invest Ophthalmol Vis Sci 47:5004-5010. CrossRef Medline

Baker H, Kawano T, Margolis FL, Joh TH (1983) Transneuronal regulation of tyrosine hydroxylase expression in olfactory bulb of mouse and rat. J Neurosci 3:69-78. CrossRef Medline

Blass EM, Teicher MH (1980) Suckling. Science 210:15-22. CrossRef Medline

Bozza T, Feinstein P, Zheng C, Mombaerts P (2002) Odorant receptor expression defines functional units in the mouse olfactory system. J Neurosci 22:3033-3043. CrossRef Medline

Bozza T, McGann JP, Mombaerts P, Wachowiak M (2004) In vivo imaging of neuronal activity neurotechnique by targeted expression of a genetically encoded probe in the mouse. Neuron 42:9-21. CrossRef Medline

Cummings DM, Belluscio L (2010) Continuous neural plasticity in the olfactory intrabulbar circuitry. J Neurosci 30:9172-9180. CrossRef Medline

Davis RE, Swiderski RE, Rahmouni K, Nishimura DY, Mullins RF, Agassandian K, Philp AR, Searby CC, Andrews MP, Thompson S, Berry CJ, Thedens DR, Yang B, Weiss RM, Cassell MD, Stone EM, Sheffield VC (2007) A knockin mouse model of the Bardet-Biedl syndrome 1 M390R mutation has cilia defects, ventriculomegaly, retinopathy, and obesity. Proc Natl Acad Sci U S A 104:19422-19427. CrossRef Medline

Dewan A, Pacifico R, Zhan R, Rinberg D, Bozza T (2013) Non-redundant coding of aversive odours in the main olfactory pathway. Nature 497: 486-489. CrossRef Medline

Doty RL, Kamath V (2014) The influences of age on olfaction: a review. Front Psychol 5:20. CrossRef Medline

Eichers ER, Abd-El-Barr MM, Paylor R, Lewis RA, Bi W, Lin X, Meehan TP, Stockton DW, Wu SM, Lindsay E, Justice MJ, Beales PL, Katsanis N, Lupski JR (2006) Phenotypic characterization of Bbs4 null mice reveals age-dependent penetrance and variable expressivity. Hum Genet 120: 211-226. CrossRef Medline

Fadool DA, Tucker K, Perkins R, Fasciani G, Thompson RN, Parsons AD, Overton JM, Koni PA, Flavell RA, Kaczmarek LK (2004) Kv1.3 channel gene-targeted deletion produces "super-smeller mice" with altered glomeruli, interacting scaffolding proteins, and biophysics. Neuron 41:389404. CrossRef Medline

Fath MA, Mullins RF, Searby C, Nishimura DY, Wei J, Rahmouni K, Davis RE, Tayeh MK, Andrews M, Yang B, Sigmund CD, Stone EM, Sheffield VC (2005) Mkks-null mice have a phenotype resembling Bardet-Biedl syndrome. Hum Mol Genet 14:1109-1118. CrossRef Medline

Feinstein P, Bozza T, Rodriguez I, Vassalli A, Mombaerts P (2004) Axon guidance of mouse olfactory sensory neurons by odorant receptors and the $\beta 2$ adrenergic receptor. Cell 117:833-846. CrossRef Medline

Feinstein P, Mombaerts P (2004) A contextual model for axonal sorting into glomeruli in the mouse olfactory system. Cell 117:817-831. CrossRef Medline

Ferrero DM, Lemon JK, Fluegge D, Pashkovski SL, Korzan WJ, Datta SR, Spehr M, Fendt M, Liberles SD (2011) Detection and avoidance of a carnivore odor by prey. Proc Natl Acad Sci U S A 108:11235-11240. CrossRef Medline

Firestein S (2001) How the olfactory system makes sense of scents. Nature 413:211-218. CrossRef Medline

Gerth C, Zawadzki RJ, Werner JS, Héon E (2008) Retinal morphology in patients with BBS1 and BBS10 related Bardet-Biedl syndrome evaluated by fourier-domain optical coherence tomography. Vision Res 48:392399. CrossRef Medline

Gopinath B, Anstey KJ, Sue CM, Kifley A, Mitchell P (2011) Olfactory impairment in older adults is associated with depressive symptoms and poorer quality of life scores. Am J Geriatr Psychiatry 19:830-834. CrossRef Medline

Haycraft CJ, Zhang Q, Song B, Jackson WS, Detloff PJ, Serra R, Yoder BK (2007) Intraflagellar transport is essential for endochondral bone formation. Development 134:307-316. CrossRef Medline

Hsu Y, Garrison JE, Kim G, Schmitz AR, Searby CC, Zhang Q, Datta P, Nishimura DY, Seo S, Sheffield VC (2017) BBSome function is required for both the morphogenesis and maintenance of the photoreceptor outer segment. PLoS Genet 13:e1007057. CrossRef Medline

Kobayakawa K, Kobayakawa R, Matsumoto H, Oka Y, Imai T, Ikawa M, Okabe M, Ikeda T, Itohara S, Kikusui T, Mori K, Sakano H (2007) Innate versus learned odour processing in the mouse olfactory bulb. Nature 450:503-508. CrossRef Medline
Kulaga HM, Leitch CC, Eichers ER, Badano JL, Lesemann A, Hoskins BE, Lupski JR, Beales PL, Reed RR, Katsanis N (2004) Loss of BBS proteins causes anosmia in humans and defects in olfactory cilia structure and function in the mouse. Nat Genet 36:994-998. CrossRef Medline

Leinders-Zufall T, Greer CA, Shepherd GM, Zufall F (1998) Imaging odorinduced calcium transients in single olfactory cilia: specificity of activation and role in transduction. J Neurosci 18:5630-5639. CrossRef Medline

Li J, Ishii T, Feinstein P, Mombaerts P (2004) Odorant receptor gene choice is reset by nuclear transfer from mouse olfactory sensory neurons. Nature 428:393-399. CrossRef Medline

Li Q, Liberles SD (2015) Aversion and attraction through olfaction. Curr Biol 25:R120-R129. CrossRef Medline

Logan DW, Brunet LJ, Webb WR, Cutforth T, Ngai J, Stowers L (2012) Learned recognition of maternal signature odors mediates the first suckling episode in mice. Curr Biol 22:1998-2007. CrossRef Medline

Low VF, Mombaerts P (2017) Odorant receptor proteins in the mouse main olfactory epithelium and olfactory bulb. Neuroscience 344:167-177. CrossRef Medline

Mandiyan VS, Coats JK, Shah NM (2005) Deficits in sexual and aggressive behaviors in Cnga2 mutant mice. Nat Neurosci 8:1660-1662. CrossRef Medline

Marks CA, Cheng K, Cummings DM, Belluscio L (2006) Activitydependent plasticity in the olfactory intrabulbar map. J Neurosci 26: 11257-11266. CrossRef Medline

McCloy RA, Rogers S, Caldon CE, Lorca T, Castro A, Burgess A (2014) Partial inhibition of Cdk1 in G2 phase overrides the SAC and decouples mitotic events. Cell Cycle 13:1400-1412. CrossRef Medline

McEwen DP, Koenekoop RK, Khanna H, Jenkins PM, Lopez I, Swaroop A, Martens JR (2007) Hypomorphic CEP290 / NPHP6 mutations result in anosmia caused by the selective loss of $\mathrm{G}$ proteins in cilia of olfactory sensory neurons. Proc Natl Acad Sci U S A 104:15917-15922. CrossRef Medline

McIntyre JC, Davis EE, Joiner A, Williams CL, Tsai IC, Jenkins PM, McEwen DP, Zhang L, Escobado J, Thomas S, Szymanska K, Johnson CA, Beales PL, Green ED, Mullikin JC; NISC Comparative Sequencing Program, Sabo A, Muzny DM, Gibbs RA, Attié-Bitach T, Yoder BK, et al. (2012) Gene therapy rescues cilia defects and restores olfactory function in a mammalian ciliopathy model. Nat Med 18:1423-1428. CrossRef Medline

Mockel A, Obringer C, Hakvoort TB, Seeliger M, Lamers WH, Stoetzel C, Dollfus H, Marion V (2012) Pharmacological modulation of the retinal unfolded protein response in Bardet-Biedl syndrome reduces apoptosis and preserves light detection ability. J Biol Chem 287:37483-37494. CrossRef Medline

Mombaerts P, Wang F, Dulac C, Chao SK, Nemes A, Mendelsohn M, Edmondson J, Axel R (1996) Visualizing an olfactory sensory map. Cell 87:675-686. CrossRef Medline

Mouly AM, Holley A (1986) Perceptive properties of the multi-site electrical microstimulation of the olfactory bulb in the rat. Behav Brain Res 21:112. CrossRef Medline

Mouly AM, Vigouroux M, Holley A (1985) On the ability of rats to discriminate between microstimulations of the olfactory bulb in different locations. Behav Brain Res 17:45-58. CrossRef Medline

Muthusamy N, Zhang X, Johnson CA, Yadav PN, Ghashghaei HT (2017) Developmentally defined forebrain circuits regulate appetitive and aversive olfactory learning. Nat Neurosci 20:20-23. CrossRef Medline

Nishimura DY, Fath M, Mullins RF, Searby C, Andrews M, Davis R, Andorf JL, Mykytyn K, Swiderski RE, Yang B, Carmi R, Stone EM, Sheffield VC (2004) Bbs2-null mice have neurosensory deficits, a defect in social dominance, and retinopathy associated with mislocalization of rhodopsin. Proc Natl Acad Sci U S A 101:16588-16593. CrossRef Medline

Papes F, Logan DW, Stowers L (2010) The vomeronasal organ mediates interspecies defensive behaviors through detection of protein pheromone homologs. Cell 141:692-703. CrossRef Medline

Pazour GJ, Rosenbaum JL (2002) Intraflagellar transport and ciliadependent diseases. Trends Cell Biol 12:551-555. CrossRef Medline

Peterlin Z, Ishizawa Y, Araneda R, Eckenhoff R, Firestein S (2005) Selective activation of G-protein coupled receptors by volatile anesthetics. Mol Cell Neurosci 30:506-512. CrossRef Medline

Peterlin Z, Li Y, Sun G, Shah R, Firestein S, Ryan K (2008) The importance of odorant conformation to the binding and activation of a representative olfactory receptor. Chem Biol 15:1317-1327. CrossRef Medline 
Reiter JF, Leroux MR (2017) Genes and molecular pathways underpinning ciliopathies. Nat Rev Mol Cell Biol 18:533-547. CrossRef Medline

Root CM, Denny CA, Hen R, Axel R (2014) The participation of cortical amygdala in innate, odour-driven behaviour. Nature 515:269-273. CrossRef Medline

Rosenbaum JL, Witman GB (2002) Intraflagellar transport. Nat Rev Mol Cell Biol 3:813-825. CrossRef Medline

Rubin BD, Katz LC (1999) Optical imaging of odorant representations in the mammalian olfactory bulb. Neuron 23:499-511. CrossRef Medline

Saraiva LR, Kondoh K, Ye X, Yoon KH, Hernandez M, Buck LB (2016) Combinatorial effects of odorants on mouse behavior. Proc Natl Acad Sci U S A 113:E3300-E3306. CrossRef Medline

Schwob JE, Jang W, Holbrook EH, Lin B, Herrick DB, Peterson JN, Hewitt Coleman J (2017) Stem and progenitor cells of the mammalian olfactory epithelium: taking poietic license. J Comp Neurol 525:1034-1054. CrossRef Medline

Slotnick B, Bodyak N (2002) Odor discrimination and odor quality perception in rats with disruption of connections between the olfactory epithelium and olfactory bulbs. J Neurosci 22:4205-4216. CrossRef Medline

Smear M, Resulaj A, Zhang J, Bozza T, Rinberg D (2013) Multiple perceptible signals from a single olfactory glomerulus. Nat Neurosci 16:16871691. CrossRef Medline

Stowers L, Holy TE, Meister M, Dulac C, Koentges G (2002) Loss of sex discrimination and male-male aggression in mice deficient for TRP2. Science 295:1493-1500. CrossRef Medline

Tadenev AL, Kulaga HM, May-Simera HL, Kelley MW, Katsanis N, Reed RR (2011) Loss of Bardet-Biedl syndrome protein-8 (BBS8) perturbs olfactory function, protein localization, and axon targeting. Proc Natl Acad Sci U S A 108:10320-10325. CrossRef Medline

Ukhanov K, Corey E, Ache BW (2016) Phosphoinositide-3-kinase is the primary mediator of phosphoinositide-dependent inhibition in mammalian olfactory receptor neurons. Front Cell Neurosci 10:97. CrossRef Medline

Verhagen JV, Wesson DW, Netoff TI, White JA, Wachowiak M (2007) Sniffing controls an adaptive filter of sensory input to the olfactory bulb. Nat Neurosci 10:631-639. CrossRef Medline

Wachowiak M, Cohen LB (2001) Representation of odorants by receptor neuron input to the mouse olfactory bulb. Neuron 32:723-735. CrossRef Medline

Ware SM, Aygun MG, Hildebrandt F (2011) Spectrum of clinical diseases caused by disorders of primary cilia. Proc Am Thorac Soc 8:444-450. CrossRef Medline

Weiss J, Pyrski M, Jacobi E, Bufe B, Willnecker V, Schick B, Zizzari P, Gossage SJ, Greer CA, Leinders-Zufall T, Woods CG, Wood JN, Zufall F (2011) Loss-of-function mutations in sodium channel Nav1.7 cause anosmia. Nature 472:186-190. CrossRef Medline

Wesson DW, Verhagen JV, Wachowiak M (2009) Why sniff fast? the relationship between sniff frequency, odor discrimination, and receptor neuron activation in the rat. J Neurophysiol 101:1089-1102. CrossRef Medline

Wetzel CH, Oles M, Wellerdieck C, Kuczkowiak M, Gisselmann G, Hatt H (1999) Specificity and sensitivity of a human olfactory receptor functionally expressed in human embryonic kidney 293 cells and Xenopus laevis oocytes. J Neurosci 19:7426-7433. CrossRef Medline

Williams CL, McIntyre JC, Norris SR, Jenkins PM, Zhang L, Pei Q, Verhey K, Martens JR (2014) Intraflagellar transport reveals distinct properties of native mammalian cilia. Nat Commun 5:5813. CrossRef Medline

Williams CL, Uytingco CR, Green WW, McIntyre JC, Ukhanov K, Zimmerman AD, Shively DT, Zhang L, Nishimura DY, Sheffield VC, Martens JR (2017) Gene therapeutic reversal of peripheral olfactory impairment in Bardet-Biedl syndrome. Mol Ther 25:904-916. CrossRef Medline

Wysocki CJ, Lepri JJ (1991) Consequences of removing the vomeronasal organ. J Steroid Biochem Mol Biol 39:661-669. CrossRef Medline

Xu W, Slotnick B (1999) Olfaction and peripheral olfactory connections in methimazole-treated rats. Behav Brain Res 102:41-50. CrossRef Medline

Zheng C, Feinstein P, Bozza T, Rodriguez I, Mombaerts P (2000) Peripheral olfactory projections are differentially affected in mice deficient in a cyclic nucleotide-gated channel subunit. Neuron 26:81-91. CrossRef Medline

Zou DJ, Chesler AT, Le Pichon CE, Kuznetsov A, Pei X, Hwang EL, Firestein S (2007) Absence of adenylyl cyclase 3 perturbs peripheral olfactory projections in mice. J Neurosci 27:6675-6683. CrossRef Medline

Zou DJ, Feinstein P, Rivers AL, Mathews GA, Kim A, Greer CA, Mombaerts P, Firestein S (2004) Postnatal refinement of peripheral olfactory projections. Science 304:1976-1979. CrossRef Medline 